\title{
Spatiotemporal Patterns of Expression of NGF and the Low-Affinity NGF Receptor in Rat Embryos Suggest Functional Roles in Tissue Morphogenesis and Myogenesis
}

\author{
Esther F. Wheeler and Mark Bothwell \\ Department of Physiology and Biophysics, University of Washington School of Medicine, Seattle, Washington 98195
}

\begin{abstract}
We show here that NGF and its low-affinity receptor (p75 ${ }^{\text {NGFP }}$ ) are expressed during rat embryogenesis at sites that are known to have important roles in tissue morphogenesis and myogenesis. The developing skin of the maxilla, the mandible, and the limb showed very similar patterns of NGF and p75 $5^{\text {NafR }}$ expression. However, NGF and P75 ${ }^{\text {NaFr }}$ expression in the developing limb initiated at the limb bud stage and was concentrated at proximal and distal developmental sites that have been reported to be involved in limb morphogenesis. Expression at the proximal/distal ends of the limb persisted throughout limb development, with some of the highest levels of expression occurring at the limb axillary sites, which were not highly innervated. We have also found p $75^{\mathrm{Narn}}$ expression at sites of mesenchymal/epithelial interactions in several developing organs that do not appear to have an adjacent source of NGF and may therefore be sites that bind and respond to the other members of the NGF family (brainderived neurotrophic factor and neurotrophin-3). These organs include the lung, testes, and kidney, where expression of p75 epithelial structures and was coexpressed with the cell adhesion molecule NCAM. In addition, we found that NGF and p75 ${ }^{\mathrm{NaFr}}$ were expressed during myogenesis. p75 ${ }^{\mathrm{NaFR}}$ was observed in myoblast cells expressing MyoD1, a myoblast differentiation marker, and NGF transcripts in cells just adjacent to the developing myoblasts. When the myoblasts differentiate into myotubes, $\mathrm{p} 75^{\mathrm{NaFr}}$ and MyoD1 cease to be expressed and the adjacent cells concomitantly cease to make NGF. However, NGF and $175^{\text {NGFr }}$ were not present in the early muscle precursor cells of the myotome of the somites but were observed in the dermatome and sclerotome,
\end{abstract}

\footnotetext{
Received May 29, 1991; revised Sept. 30, 1991; accepted Oct. 18, 1991.

We thank Dr. Margaret Fahnestock for the Mastomys rat cDNA and Dr. Harold Weintraub for the MyoD1 transcription vector. We thank Dr. Margaret Byers for many helpful discussions and review of the manuscript and Dr. Stephen Hauschka for helpful discussions on the development of muscle. We are grateful to Dr. Chris von Bartheld for manuscript reviews and for helpful suggestions on the figures. We also acknowledge Phyllis Harbor and Lorraine Gibbs for excellent technical assistance. This work was supported by National Institute of Heart and Lung Grant HL43397 to M.B.

The monoclonal antibody against rat NCAM was obtained from the Developmental Studics Hybridoma Bank maintained by the Department of Pharmacology and Molecular Sciences, Johns Hopkins University School of Medicine, Baltimore, MD and the Department of Biology, University of Iowa, Iowa City, IA under NICHD Contract NO1-HD-6-2915.

Correspondence should be addressed to Mark Bothwell, Ph.D., Department of Physiology and Biophysics, Health Science Building SJ-40, University of Washington School of Medicine, Seattle, WA 98195.

Copyright (C) 1992 Society for Neuroscience $0270-6474 / 92 / 120930-16 \$ 05.00 / 0$
}

respectively. These results suggest that NGF and p75 have functional roles in developmental processes that affect morphogenesis and cell differentiation.

NGF is a target-derived neurotrophic factor that has distinct functional effects on the developing nervous system. It is the prototypic molecule of the family of neurotrophins (Bothwell, 1991) and is essential for the development, survival, and differentiation of the peripheral sympathetic and sensory neurons (Greene and Shooter, 1980; Levi-Montalcini, 1987; Thoenen et al., 1987). Although the role of NGF as a neurotrophic regulator has been studied extensively, there are several reports that suggest the molecule may have broader physiological effects. For example, NGF has been reported to be expressed by the luminal epithelium of the epididymis and the germ cells of the rat and mouse testes (Ayer-LeLievre et al., 1988) and to affect the morphology and function of Sertoli and lamina propria cells of the testis (Seidl and Holstein, 1990). In addition, NGF has been shown to promote the differentiation of muscle cells in culture (Brodie and Sampson, 1990).

Like NGF, the low-affinity form of the NGF receptor ( $75^{\mathrm{NGFR}}$ ) has been observed to be expressed in certain non-neuronal tissues during embryogenesis in patterns that cannot be easily correlated with neural development. Analyses in our laboratory and in others have shown that a wide array of non-neuronal cells express p $75^{\text {NGFR }}$ during development or as a consequence of tumorogencsis (Buck et al., 1987; Ernfors et al., 1988, 1990; Thomson et al., 1988, 1989; Yan and Johnson, 1988; Thompson et al., 1989; Byers et al., 1990). p75 ${ }^{\text {NGFR }}$ has been reported in embryonic tissues that undergo extensive morphogenesis and cellular differentiation, such as the limb bud and the somites (Ernfors et al., 1988; Hallböök et al., 1990). p75 ${ }^{\text {NGFR }}$ expression has also been reported at sites of mesenchymal/epithelial interactions that affect tooth morphogenesis (Byers et al., 1990) and the development of the otocyst (von Bartheld et al., 1991). Furthermore, $\mathrm{p} 75^{\mathrm{NGFR}}$ expression in the developing tooth and otocyst begins well before the developing structures become innervated. The variety of non-neuronal cells that express $\mathrm{p} 75^{\mathrm{NGFR}}$ during embryogenesis raises the possibility that this molecule mediates functions separate from promotion of innervation. In addition, recent reports have shown that $\mathrm{p} 75^{\mathrm{NGFR}}$ binds other members of the neurotrophin family (Hohn et al., 1990; Rodrigucz-Tcbar ct al., 1990), suggesting that the low-affinity receptor's function is broader and more complex than previously defined.

To understand better the roles of NGF and $p 75^{\mathrm{NGFR}}$ in the 
developing embryo, we used in situ hybridization to localize sites of NGF and p $75^{\mathrm{NGFR}}$ transcript synthesis relative to each other in adjacent sections of rat embryos at different stages of development. We reasoned that locating the sites of NGF biosynthesis relative to $\mathrm{p} 75^{\mathrm{NGFR}}$ would identify developing systems in which NGF mediates cell-cell interactions. We compared NGF and p $75^{\text {NGFR }}$ expression patterns in the developing epithelium in regions of the skin that are highly innervated, such as the maxillary pad, relative to the expression patterns in the epithelial regions of the developing limb, which has been reported to express high levels of p75 ${ }^{\text {NorR }}$ as early as the limb bud stage (Ernfors et al., 1988; Heuer et al., 1990). We included in this study organ systems that express p75 thelial/mesenchymal interactions but, unlike the developing tooth and otocyst, do not become highly innervated and therefore remain unexplained in terms of a prototypic NGF response. We also examined developing muscle and the somites, which have been reported to express p $75^{\text {NGFR }}$ (Ernfors et al., 1988; Yan and Johnson, 1988; Heuer et al., 1990) but have not been shown to require NGF for neurotrophic regulation (Thoenen and Barde, 1980; Davies et al., 1987b; Yan et al., 1988; Oppenheim, 1989). By comparing NGF and $\mathrm{p} 75^{\mathrm{NGFR}}$ expression relative to innervation and other developmental events occurring in these nonneuronal tissues, we have found that these molecules are frequently associated with morphogenetic events and myogenesis in a manner that seems unrelated to neural development. The results reported here suggest that NGF and $\mathrm{p} 75^{\mathrm{NGFR}}$ may have a direct role in the regulation of morphogenesis and myogenesis.

\section{Materials and Methods}

Rat embryos. All embryos were obtained from Sprague-Dawley rats. Noon on the day of vaginal plug was considered $0.5 \mathrm{~d}$ postcoitum.

Tissue fixation and processing. Embryos and tissues subjected to immunocytochemical analysis were fixed in methyl Carnoy's fixative $(60 \%$ methanol, 30\% chloroform, $10 \%$ glacial acetic acid) for $24 \mathrm{hr}$ and processed for paraffin embedding. Embedded tissues were sectioned at 8 $\mu \mathrm{m}$ and mounted onto gelatin- or polylysine-coated slides.

Embryos and tissues for in situ hybridization were fixed in $10 \%$ neutral formalin for $24 \mathrm{hr}$ and washed for $30 \mathrm{~min}$ each in the following consecutive washes: $0.1 \mathrm{M}$ sodium monophosphate, $0.5 \mathrm{M}$ sodium chloride $50 \%$ ethanol containing $1.25 \%$ sodium chloride, and three washes of $70 \%$ ethanol. Tissucs were then processed for paraffin embedding, serial sectioned at $8 \mu \mathrm{m}$, and mounted onto polylysine- or silane-coated slides.

Plasmid constructs and in vitro $R N A$ probe synthesis. The NGF cDNA from the Mastomys rat was provided by M. Fahnestock (Fahnestock and Bell, 1988). A 1 kilobase (kb) EcoRI/Pstl fragment encoding the entire $\beta$-NGF gene was subcloned into the pGEM7Z $(f+)$ transcription vector (Promega Biotec). A cDNA containing the first two exons of the rat NGF receptor was provided by M. Chao (Radeke et al., 1987). A 250 base pair (bp) EcoRI/BamHI fragment encoding the $5^{\prime}$ end of the receptor was subcloned into pGEM3Z $(\mathbf{f}+)$ (Promega). The MyoD1 transcription vector was provided by Dr. H. Weintraub from the Fred Hutchinson Cancer Research Center.

${ }^{35}$ S-UTP-labeled single-stranded sense and antisense RNA riboprobes were prepared according to Melton et al. (1984). From both constructs, RNA antisense probes were synthesized using SP6 polymerase on templates linearized with BamHI. Sense probes were generated by T7 polymerase reaction with DNA templates linearized with EcoRI. Five hundred nanograms of each template were transcribed in vitro in a $25 \mu \mathrm{l}$ vol containing $100 \mu \mathrm{Ci}{ }^{35} \mathrm{~S}-\mathrm{UTP}(1320 \mathrm{Ci} / \mathrm{mmol}$ from New England Nuclear Research Products or Amersham Corp.). Reactions were incubated at $37^{\circ} \mathrm{C}$ for $2 \mathrm{hr}$. After $1 \mathrm{hr}$ of incubation, $1 \mu \mathrm{l}$ of fresh enzyme was added to each reaction mix. The resulting RNA transcripts were degraded to an average length of $150 \mathrm{bp}$ using alkaline hydrolysis according to Cox et al. (1984). Hydrolized probes were ethanol precipitated and resuspended in a $100 \mu \mathrm{l}$ vol to yield transcripts with a specific activity ranging from 2 to $3.5 \times 10^{6} \mathrm{dpm} / \mathrm{ng}$.

In situ hybridization procedure. In situ hybridization was performed according to Angerer et al. (1987). Hybridrization was carried out in $2 \times \operatorname{SSPE}\left(0.3 \mathrm{~m} \mathrm{NaCl}, 10 \mathrm{~mm} \mathrm{NaH} \mathrm{PO}_{4}\right.$, and $1 \mathrm{~mm}$ EDTA), $50 \%$ formamide, $20 \mathrm{~mm}$ Tris- $\mathrm{HCl}(\mathrm{pH} \mathrm{7.5),} 5 \mathrm{~mm}$ EDTA, $10 \%$ dextran sulfate, $5 \times$ Denhardt's solution, $20 \mathrm{~mm}$ dithiothreitol, $0.5 \mathrm{mg} / \mathrm{ml}$ yeast $t \mathrm{RNA}$, and $5 \times 10^{6} \mathrm{cpm} / \mathrm{ml}(10 \mathrm{ng} / \mathrm{ml})$ of RNA probe in a $50 \mu \mathrm{lol}$ at $50^{\circ} \mathrm{C}$ for $16 \mathrm{hr}$. After hybridization, sections were washed twice in $4 \times$ SSPE for $15 \mathrm{~min}$ at room temperature and then in $50 \%$ formamide, $2 \times$ SSPE at $65^{\circ} \mathrm{C}$ for $10 \mathrm{~min}$. This hybridization was followed by a 1 min wash in $2 \times$ saline-sodium citrate (SSC) to remove formamide, and then sections were subjected to RNase A digestion $(2 \mu \mathrm{g} / \mathrm{ml}$ in $10 \mathrm{~mm}$ Tris- $\mathrm{HCl}, \mathrm{pH} 7.5,1 \mathrm{~mm}$ EDTA) for $30 \mathrm{~min}$ at $37^{\circ} \mathrm{C}$. Digestion was followed by a $30 \mathrm{~min}$ wash in $10 \mathrm{~mm}$ Tris- $\mathrm{HCl}(\mathrm{pH} 7.5)$ and $1 \mathrm{~mm}$ EDTA, a second $10 \mathrm{~min}$ wash in $50 \%$ formamidc containing $2 \times$ SSPE at $65^{\circ} \mathrm{C}$, and a $30 \mathrm{~min}$ wash in $2 \times \mathrm{SSC}$. A high-stringency wash in $0.1 \times$ SSC was then done at $65^{\circ} \mathrm{C}$ for $15 \mathrm{~min}$ and was followed by a $30 \mathrm{~min}$ wash in $0.1 \times$ SSC at room temperature. Sections were then dehydrated through graded ethanols containing $6 \mathrm{~mm}$ ammonium acetate, dried, and coated with photographic emulsion (NTB-2, Eastman Kodak Co.) for autoradiography (Angerer et al., 1987). The sections were exposed at $4^{\circ} \mathrm{C}$ for 3-5 weeks and were developed, counterstained with either cresyl violet or methyl green, and coverslipped with Permount. Sections were examined under both bright- and dark-field illumination.

Immunohistochemistry. For immunoreaction, the mounted tissue sections were deparaffinized in xylene for $30 \mathrm{~min}$, rehydrated through graded ethanol solutions, and reacted for $45 \mathrm{~min}$ with $0.3 \%$ hydrogen peroxide in methanol to inactivate endogenous peroxidases. Nonspecific staining was inhibited by preincubating the sections for $2 \mathrm{hr}$ in a solution containing phosphate-buffered saline (PBS), $2.5 \%$ horse serum, and $2.5 \%$ rat serum. Primary and secondary antibodies were also diluted and applied in this solution. The primary monoclonal antibody $192-\mathrm{IgG}$ (Chandler et al., 1984) was used at a concentration of $3 \mu \mathrm{g} / \mathrm{ml}$. The monoclonal antibody against $\mathrm{N}-\mathrm{CAM}(5 \mathrm{~B} 8)$ was obtained from the Developmental Studies Hybridoma Bank (see acknowledgments) as a hybridoma culture supernate and was used at a 1:10 dilution. The monoclonal antibody to neurofilament protein $68 \mathrm{D}$ was obtained from Boehringer Mannheim and was used at $5 \mu \mathrm{g} / \mathrm{ml}$. Tissue sections were incubated in primary antibody for $3-4 \mathrm{hr}$ at room temperature and then overnight at $5^{\circ} \mathrm{C}$. After extensive washes in PBS, the sections were reacted for $4 \mathrm{hr}$ at room temperature with secondary antibody (biotinylated horse anti-mouse IgG; Vector Inc.) at a concentration of $7.5 \mu \mathrm{g} /$ $\mathrm{ml}$. Sections were again washed exhaustively as above and reacted with streptavidin aminohexanonyl-biotin complex (Zymed Laboratories) at the manufacturers suggested dilutions. The immunocomplexed sections were carried through several PBS washes followed by at least two washes in $1 \mathrm{~m}$ sodium acetate, $\mathrm{pH}$ 6.1. The resulting immune complexes have peroxidase activity that yields a black reaction product when reacted for $4 \mathrm{~min}$ with $0.3 \%$ hydrogen peroxide, $0.034 \mathrm{mg} / \mathrm{ml}$ diaminobenzidine, and $0.025 \mathrm{gm} / \mathrm{ml}$ nickel sulfate in $0.1 \mathrm{M}$ sodium acetate, $\mathrm{pH} 6.1$. After peroxidase reaction, the sections were counterstained with either hematoxylin or methyl green, dehydrated through graded ethanol solutions, dipped in Histoclear, and mounted with coverslips and Permount mounting medium. Sections were analyzed for immunostaining by light microscopic analysis.

\section{Results}

We localized the sites of NGF expression relative to its lowaffinity receptor, $\mathrm{p} 75^{\mathrm{NGFR}}$, by conducting in situ hybridization analysis on developing rat embryos. Hybridization sites of antisense riboprobes for NGF were compared to sites of antisense p $75^{\text {NGFR }}$ hybridization in adjacent sections of rat embryos from embryonic day 12.5 to 22 (stages E12.5-E22). The expression of both molecules relative to innervation patterns was monitored by immunohistochemical localization of NCAM, which is expressed on the surface of neurons (Edelman, 1984), and p75 NGFR, which is expressed by Schwann cells that ensheath nerve fibers (Johnson et al., 1988). Both monoclonal antibodies proved to be sensitive probes for nerve fiber location. However, since both $\mathrm{p} 75^{\mathrm{NGFR}}$ and NCAM were found to be expressed by certain mesenchymal populations, monoclonal antibodies to neurofilament protein were also used when necessary to locate nerve fibers. 

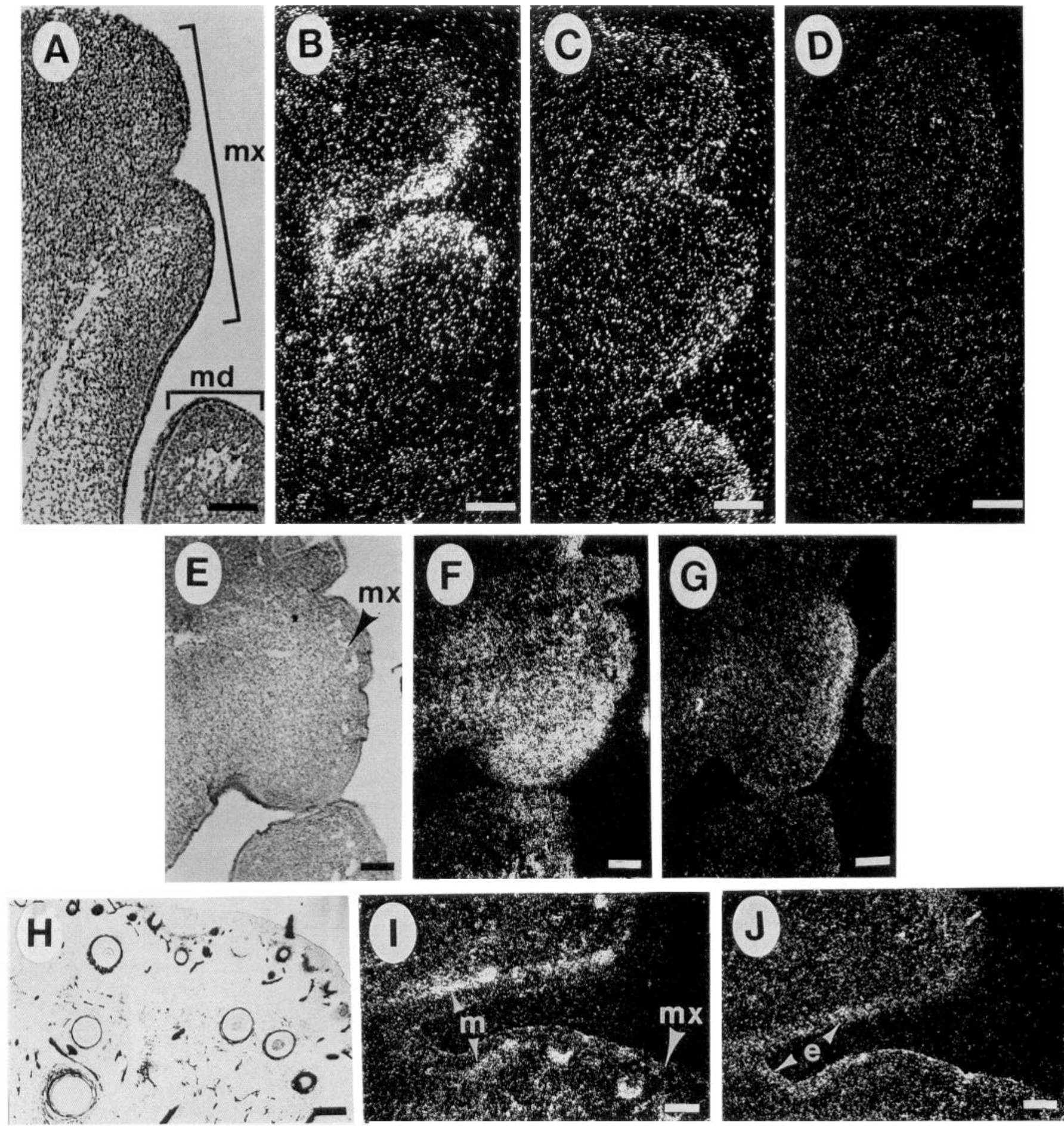

Figure 1. Expression of NGF and p $75^{\text {NGFR }}$ transcripts in the rat embryo maxillary and mandibular processes. A, Bright-field photomicrograph of a hematoxylin and eosin-stained section through the first branchial arch of an E13.5 embryo. The first branchial arch later develops into the maxilla $(m x)$ and mandible $(m d)$ processes. This section is adjacent to the section shown in $B . B$, Dark-field photomicrograph of section through the first branchial arch of an E13.5 embryo hybridized with antisense p $75^{\mathrm{NGFR}}$ riboprobe. Expression of p $75^{\mathrm{NGFR}}$ transcripts is confined to the nasal cleft. $C$, Dark-field photomicrograph of the first branchial arch from section adjacent to $B$ and hybridized with antisense NGF riboprobe. Note expression in the epithelium and mesenchyme of both processes. $D$, Dark-field photomicrograph of the first branchial arch from section adjacent to $C$. Section was hybridized to sense NGF riboprobe as a negative control. $E$, Bright-field photomicrograph of hematoxylin and eosin-stained section through the maxilla $(m x)$ and mandible of an E15.5 embryo. Section is adjacent to $F$. $F$, Dark-field photomicrograph of section through the maxilla and mandible of an E15.5 embryo hybridized to p75 NGFR antisense riboprobe. Note the extensive p75 ${ }^{\mathrm{NGFR}}$ expression throughout the mesenchyme of the maxillary process. $G$, Dark-field photomicrograph of section adjacent to $F$ and hybridized to NGF antisense riboprobe. Note transcripts are confined to the epithelia and subjacent mesenchyme of both processes. $H$, Bright-field photomicrograph of section through the maxillary pad of an E18.5 embryo. This section was immunoreacted with monoclonal antibody 192-IgG against rat p75 black stain on the nerve fibers and the mesenchyme surrounding the vibrissae. $I$, Dark-field photomicrograph of section through the maxilla ( $m x$ ) and mandible of an E18.5 embryo hybridized to p7 $5^{\text {NGFR }}$ antisense riboprobe. Note p75 NGFR mRNA is present in the mesenchyme $(m)$ underlying the epithelium and surrounding the vibrissae. $J$, Dark-field photomicrograph of section adjacent to $F$ and hybridized to NGF antisense riboprobe. Note high level of transcripts in both the epithelial $(e)$ and mesenchymal layers of the skin at the jaw axilla. Scale bars, $100 \mu \mathrm{m}$. 
NGF and p75 $5^{\text {NGF }}$ expression in the developing epidermis

We examined NGF and p $75^{\text {NGFR }}$ expression in the developing rat maxillary pad in order to compare the results from our experimental approach with similar data generated for the mouse maxillary pad (Davies et al., 1987a; Wyatt et al., 1990). We found close agreement between the two species on timing of innervation and spatiotemporal expression of NGF and $\mathrm{p} 75^{\mathrm{NGFR}}$. As shown in Figure 1, p $75^{\mathrm{NGFR}}$ and NGF transcripts were present in the maxillary and mandibular processes of the first branchial arch in the E13.5 rat embryo, the stage (Fig. $1 A-D$ ) at which the earliest trigeminal axons arrived at the developing rat maxillary pad. NGF transcripts were present in the epithelium and subjacent mesenchyme of the maxillary and mandibular epidermis. By contrast, p75 ${ }^{\text {NGFR }}$ biosynthesis was confined to the mesenchyme of the nasal cleft. By E15.5, the concentration of p75 ${ }^{\text {NGFR }}$-immunoreactive nerve fibers in the maxilla had reached its peak (data not shown). At this stage, p75 vGrR transcripts had reached maximal levels of expression in the mesenchymal component throughout the maxillary and mandibular processes (Fig. $1 F$ ). By E18.5 (Fig. $1 H-J$ ), p75 ${ }^{\mathrm{NGFR}}$ immunoreactivity (Fig. $1 H$ ) was localized in the mesenchymal cell layers underlying the skin epithelium and surrounding the vibrissae. Localization of $\mathrm{p} 75^{\mathrm{NGFR}}$ antisense riboprobes matches the results of the immunohistochemical analysis (Fig. $1 H, I$ ). It is clear at this stage that p $75^{\mathrm{NGFR}}$ transcripts appear in the mesenchymal cell layer (Fig. $1 I$ ) while NGF transcripts are localized in the epithelium and the underlying mesenchymal cell layer of the skin (Fig. 1.J). Therefore, as for the mouse maxillary pad (Davies et al., 1987a; Wyatt et al., 1990), NGF biosynthesis preceded $\mathrm{p} 75^{\mathrm{NGFR}}$ biosynthesis in the rat maxillary epidermis and was expressed by both the epithelial and mesenchymal components of the developing skin. By contrast, $\mathrm{p} 75^{\mathrm{NGFR}}$ biosynthesis began in the epidermis $1 \mathrm{~d}$ later and peaked $1-1.5 \mathrm{~d}$ after NGF biosynthesis had maximized. Unlike NGF, p75 ${ }^{\mathrm{NGFR}}$ was expressed only in the mesenchymal components of the epidermis. Synthesis of both molecules began after the arrival of nerve fibers from the trigeminal ganglion.

We next examined the innervation and expression of NGF and $p 75^{\text {NGFR }}$ in other regions of the developing epidermis. Surprisingly, the patterns of NGF and p $75^{\text {NGFR }}$ expression in the maxillary epidermis also occurred in other regions of the developing embryo that, unlike the maxillary pad, are not highly innervated. Although we observed a remarkable degree of variability in the content of NGF transcripts in various regions of the developing epidermis, we found that the highest levels of NGF transcripts were consistently present in epidermal regions that also contained high levels of $p 75^{\text {NGFR }}$ transcripts in the adjacent mesenchyme. Furthermore, the highest concentration of NGF and $p 75^{\text {NGFR }}$ transcripts in the developing epidermis appeared consistently at axillary sites where the limb joins the body (Fig. 2), the head joins the body (data not shown), and the mandible joins the maxilla (Fig. $1 I, J$ ). This general pattern of expression can be clearly illustrated by examining the epidermis of the developing limb. As shown in Figure 2, NGF and p75 $5^{\text {NGFR }}$ transcripts were most highly concentrated in the skin at the limb axilla (Fig. 2A-C) and at the distal end of the developing foot (Fig. 2D-F). This patttern of NGF and $\mathrm{p} 75^{\mathrm{NGFR}}$ expression was first observed in the E13.5 limb bud, with NGF and p75 NGFR transcripts occurring in the mesenchyme adjacent to the apical ectodermal ridge and at the sites of limb attachment (Fig. 3). Expression of NGF and p75 NGFR transcripts at these proximal and distal sites of the limb continued through E22, the latest stage examined.

Unlike the maxillary pad, the high levels of NGF and p75 transcripts at the axilla do not correlate with high levels of innervation. This is illustrated in Figure 4 , where p $75^{\mathrm{NGFR}}$ and NCAM are localized immunohistochemically to demonstrate mesenchymal expression of receptor relative to the location of the nerve fibers at the limb axilla. The expression of $\mathrm{p} 75^{\mathrm{NGFR}}$ in the skin of the limb axilla (Fig. $4 B$ ) was comparable to that of the highly innervated maxilla (Fig. $4 A$ ) and toe (Fig. $4 C$ ). However, by comparing $p 75^{\mathrm{NGFR}}$-immunoreactive sites with NCAMimmunoreactive cells in the fore- and hindlimb axilla (Fig. $4 D-$ $G)$, we found that the axillary junctions were considerably less innervated than the maxilla or toe (Fig. $4 A, C$ ). The low concentration of nerve fibers shown here for the limb axilla is representative of other axillary points where we observed high levels of NGF and p75 ${ }^{\text {NGFR }}$ expression.

\section{p7 $5^{\text {NGFR }}$ expression during organogenesis of the lung, testes, and kidney}

Mesenchymal/epithelial interactions play an important role in the morphogenesis of the lung, testes, and kidney (see Fallon et al., 1983, for overview). During organogenesis of the lung, mesenchymal/epithelial interactions have been shown to affect the development of the trachea and bronchioles (Spooner and Wessels, 1970; Wessels, 1970; Hilfer et al., 1985). The development of the embryonic lung is characterized by four distinct developmental stages: the pseudoglandular phase, the canalicular phase, the saccular phase, and the alveolar phase. The pseudoglandular phase in the rat occurs between E12 and E20 and is the period when the trachea and the bronchial airways form. The developing epithelia that form the airways are surrounded by "instructive" mesenchymal cells that are presumably involved in the morphogenesis of the bronchial epithelium.

From E15.5 to E18.5, the period when the bronchiole tubes are being formed, we obscrved p $75^{\mathrm{NGF}}$ expression by the mesenchymal cells that were located adjacent to the developing

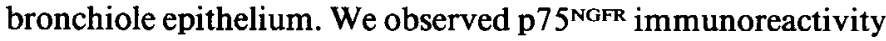
and mRNA transcripts in the mesenchymal cells surrounding the tracheal epithelium at E14.5, prior to innervation of the lung (data not shown). At E15.5, p75 ${ }^{\text {NGFR }}$ transcripts and immunoreactivity were detected on the mesenchymal cells surrounding the bronchiole epithelium. As shown in Figure $5 A$, dense p $75^{\text {NGIR }}$ immunoreactivity was localized on the mesenchymal cells surrounding the bronchiole epithelium at E16.5. In situ hybridization of E16.5 embryos showed p75 NGFR transcripts localized to this same mesenchymal cell population (Fig. $5 B, D$ ). At this stage, the main bronchiole tubes were surrounded by NCAMimmunoreactive nerve fibers. However, nerve fibers were not seen around the secondary branches.

NGF transcripts were not detected in the lung (Fig. 5C). Since the mesenchymal cells expressing p $75^{\text {NGFR }}$ appear to have no adjacent source of NGF, the receptor on these cells could be responding to one of the other neurotrophic factors [neurotrophin-3 (NT3) or brain-derived neurotrophic factor (BDNF)], which have both been shown to bind the p75 ${ }^{\text {NGFR }}$ (Hohn et al., 1990; Rodriguez-Tebar et al., 1990). However, the possibility that NGF transcripts could have been present at very low levels cannot be excluded.

E16.5 was the first stage during which we observed nerve fiber ingrowth into the bronchiole area. As shown in Figure $6 A$, 

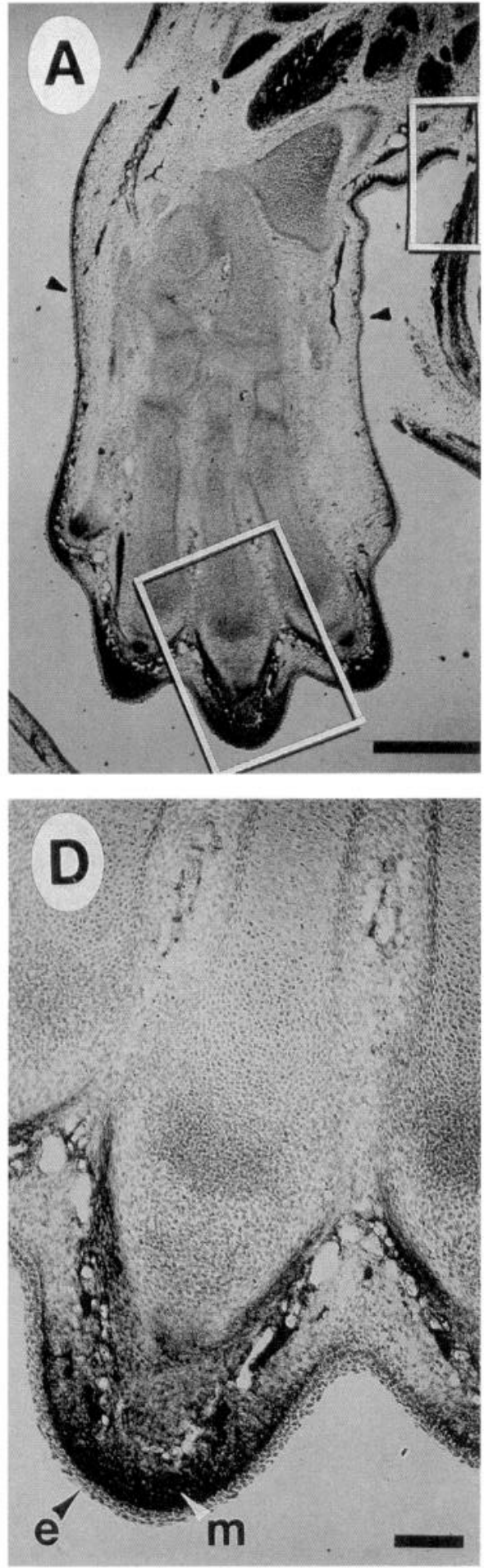
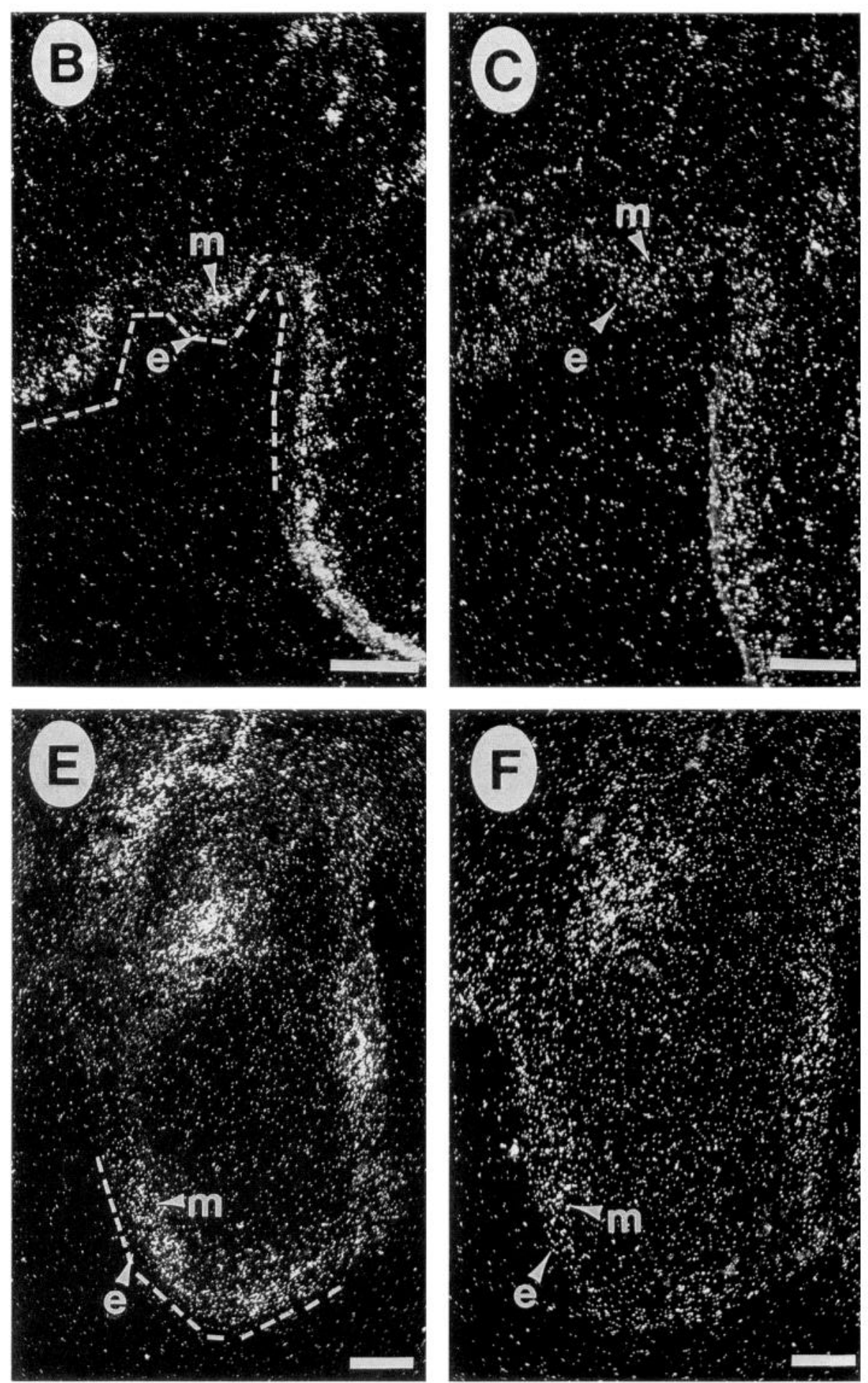

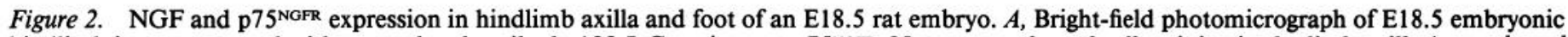
hindlimb immunoreacted with monoclonal antibody $192-\mathrm{IgG}$ against rat p75 ${ }^{\mathrm{NGFR}}$. Note mesenchymal cell staining in the limb axilla (upper boxed area) as compared to the skin mesenchyme located midlimb (arrowheads). B, Dark-field photomicrograph of E18.5 embryonic hindlimb axilla hybridized to antisense p $75^{\text {NGFR }}$ riboprobe. This section is comparable to the area in the upper boxed area in $A$. Note similarity to patterns of expression in the jaw axilla shown in Figure 1I. $C$, Dark-field photomicrograph of section adjacent to $B$ and hybridized to antisense NGF riboprobe. Note similarity to patterns of expression in the jaw axilla shown in Figure $1 J$. D. Bright-field photomicrograph at higher magnification of the toes (lower boxed area in $A$ ). E, Dark-field photomicrograph of E18.5 toe (comparable to section in $D$ ) hybridized to antisense p75 Dark-field photomicrograph of section adjacent to $E$ and hybridized to antisense NGF riboprobe. $e$, epithelium; $m$, mesenchyme. Scale bars: $A$, $0.5 \mathrm{~mm} ; B-F, 100 \mu \mathrm{m}$. 

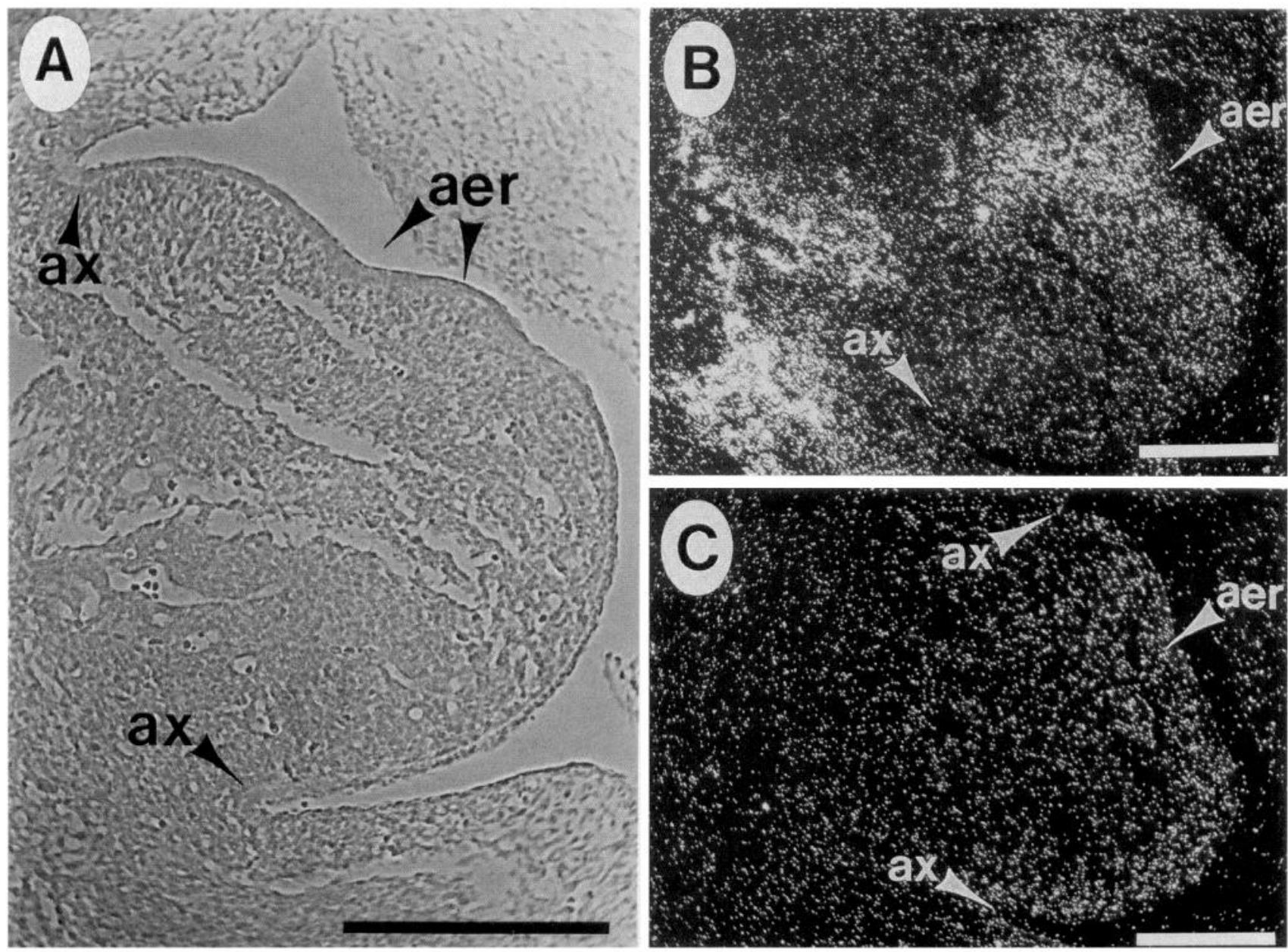

Figure 3. Expression of $\mathrm{p} 75^{\mathrm{NGFR}}$ and NGF in the limb bud at E13.5. A, Bright-field photomicrograph of the rat embryonic limb bud at stage E13.5. Note the apical ectodermal ridge (aer) and the axillary junctions (ax) where the limb joins the body wall. $B$, Dark-field photomicrograph of the limb bud shown in $A$. Section was hybridized to riboprobe encoding antisense p $75^{\mathrm{NGFR}}$. Note the concentration of grains subjacent to the apical ectodermal ridge (aer) and at the limb bud axilla $(a x)$. $C$, Dark-field photomicrograph of the limb bud section adjacent to $B$. Section was hybridized to riboprobe encoding antisense NGF. Note the concentration of grains at the axilla (ax) and along the ectodermal ridge (aer) of the developing bud. Scale bars: $A, 500 \mu \mathrm{m} ; B$ and $C, 200 \mu \mathrm{m}$.

NCAM-immunoreactive fibers can be detected along the main bronchiole branches. Interestingly, NCAM is also being expressed at low levels in the p $75^{\text {NGFR }}$-positive bronchiole mesenchymal populations. By E17.5, p $75^{\text {NGFR }}$ expression in the bronchiole mesenchyme had reached its peak. At the peak of p $75^{\text {NGFR }}$ expression, NCAM was also increased in the bronchial mesenchyme. As shown in Figure $6, A$ and $B$, the pattern of NCAM immunoreactivity in the mesenchyme surrounding the bronchioles at E18.5 is virtually identical to that of p75 NCAM and p $75^{\text {NGFR }}$ were coexpressed by the bronchiole mesenchyme until E19.5, when both molecules concomitantly ceased to be expressed.

Although p $75^{\text {NGFR }}$ was expressed by the lung mesenchyme just prior to innervation, the regions that these cells occupy during bronchial morphogenesis are the only areas that become innervated. This is shown in Figure 6, $C$ and $D$, by the p $75^{\text {NGFr }}$ and NCAM immunoreactivity on the nerve fibers surrounding the bronchiole tubes of an E20.5 rat embryo, a stage when mesenchymal p $75^{\mathrm{NGFR}}$ and NCAM have ceased to be expressed. Therefore, p $75^{\text {NGFR }}$ expression in the mesenchyme of the developing lung bronchioles precedes ingrowth of nerve fibers and
NCAM expression by 1.5-2 d. Both molecules were expressed by the mesenchyme adjacent to epithelia during bronchiole morphogenesis and occupied tissue areas that ultimately became innervated.

The pattern of $\mathrm{p} 75^{\mathrm{NGFR}}$ expression observed in mesenchyme of the developing testes was very similar to that described above for the lung. As shown in Figure 7, $A$ and $B$, immunohistochemical localization of $\mathrm{p} 75^{\mathrm{NGFR}}$ was confined to the mesenchymal cells that surrounded the developing seminiferous tubules. p75 $7{ }^{\mathrm{NGFR}}$ transcripts were also localized in this cell population (Fig. $7 \mathrm{C}$ ). As in the lung, the mesenchyme of the testes expressed both NCAM and $\mathrm{p} 75^{\mathrm{NGFR}}$ expression but $\mathrm{p} 75^{\text {NGFR }}$ expression preceded NCAM expression by several days. p $75^{\text {NGFR }}$ was first detected in the testes mesenchyme at E14.5, but these cells did not coexpress p $75^{\mathrm{NGFR}}$ and NCAM until E20.5 (data not shown). Like the lung, p $75^{\text {NGFR }}$ was expressed by adjacent mesenchymal cell populations at a time when tubular epithelial structures form but, interestingly, the seminiferous tubules do not become innervated (Geneser, 1986). Innervation of the testes is confined to the vasculature of this organ.

As in the lung, we were unable to detect NGF transcripts in 
Figure 4. Comparison of mesenchymal p75 $5^{\text {NGFR }}$ expression and innervation of the skin at the limb axilla relative to that of the highly innervated maxillary pad and the toe. The brightfield photomicrographs pictured in $A$ $C$ were taken from different regions of a single section of an E18 rat embryo immunoreacted with monoclonal antibody $192-\mathrm{IgG}$ against rat $\mathrm{p} 75^{\mathrm{NGFR}}$. $A$, Maxillary pad. Note location of immunoreactive nerve fibers $(n)$ and mesenchyme $(m) . B$, p $75^{\text {NGFR }}$ immunoreactivity in the limb axilla. Note similarity in levels of $\mathrm{p} 75^{\mathrm{NGFR}}$ immunoreactivity relative to $A$ and $C$. $C$, p75 NGFr immunoreactivity in the toe. $D$, Brightfield photomicrograph of $\mathrm{p} 75^{\text {NGFR }}$ immunoreactivity at the hindlimb axilla of the same E18 embryo but at a different plane of section. $E$, NCAM-immunoreactive nerve fibers $(n)$ in the section adjacent to $D$. Note levels of innervation relative to $A$ and $C . F$, Bright-field photomicrograph of p75 NGFr-immunoreactive nerve fibers and mesenchyme $(m)$ in the forelimb. $G$, NCAM-immunoreactive nerve fibers in the section adjacent to $F$. $e$, epithelium; $m u$, muscle. Scale bars, 100 $\mu \mathrm{m}$.
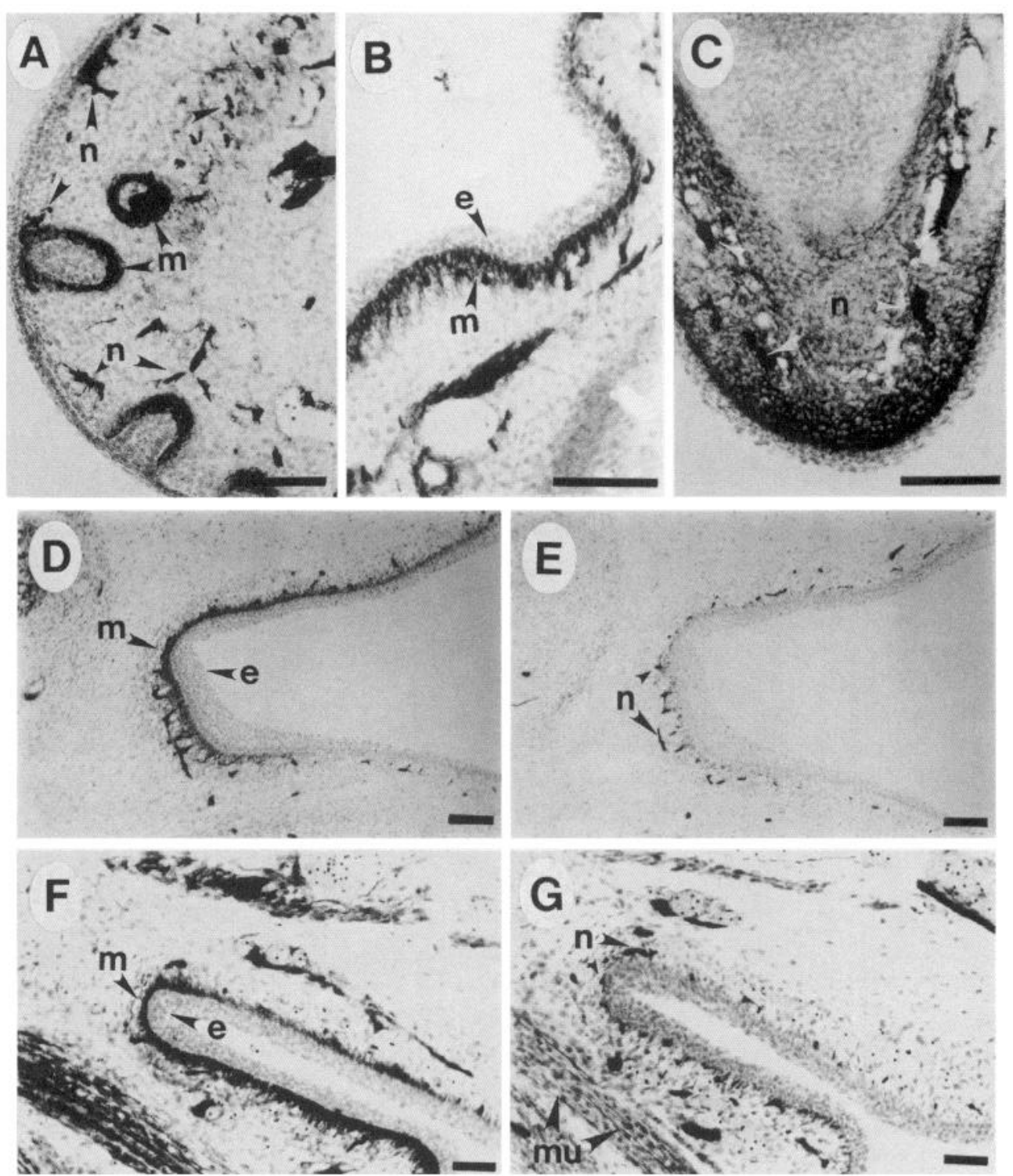

the cells of the testes (Fig. 7D). If indeed NGF transcripts were present, they were in these organs at very low levels since the sections shown here also contained NGF transcript signals in the epithelium and muscle comparable to those shown in Figures 1 and 2 (see also Fig. 9). The mesenchymal cells of the developing testes may utilize one of the other factors of the NGF family.

The glomeruli of the developing kidney form from polarizing epithelium that is mesenchymal in origin (Saxen, 1987). p75 NGFR expresses at high levels in this polarizing epithelium as the glomeruli begin to undergo morphogenesis. Both p $75^{\text {NGFR }}$ transcripts and protein were detected in the kidney glomeruli (data not shown). p75 ${ }^{\text {NGFR }}$ expression was first detected at E14.5 and was still ongoing at E22. Like the lung and the testes, NGF transcripts were not observed in any cell type of the developing kidney. Interestingly, the neurotrophic factor NT3 has been reported to express in the adult kidney glomeruli (Ernfors et al., 1990).

The kidney glomeruli are similar to the seminiferous tubules in that they do not become innervated. Innervation of the kidney is confined to the tubules and the vasculature that infiltrate the mature Bowman's capsule (Tisher, 1981). To confirm that the developing glomeruli were also devoid of innervation, neurofilament immunoreactivity (Fig. $8 A$ ) in the kidney glomeruli was examined relative to that of $\mathrm{p} 75^{\mathrm{NGFR}}$ (Fig. $8 B$ ). Neurofilament protein was present in nerve fibers surrounding the kidney tubules but was absent from the glomeruli. As shown in Figure $8 C$, NCAM was expressed by the glomerular epithelium during their morphogenesis in patterns similar to those of $\mathrm{p} 75^{\mathrm{NGFR}}$. NCAM immunoreactivity was also present in the kidney mesenchyme.

\section{NGF and p75 NGFR expression in developing muscle}

p75 ${ }^{\text {NGFR }}$ immunoreactivity has been reported to occur in developing muscle (Yan and Johnson, 1988), but NGF is not involved in either motor or proprioceptive sensory innervation of the muscle (Thoenen and Barde, 1980; Davies et al., 1987b; Yan et al., 1988; Oppenheim, 1989). However, we observed high levels of NGF mRNA in close proximity to p75 scripts in developing muscle. Our immunohistochemical ob- 

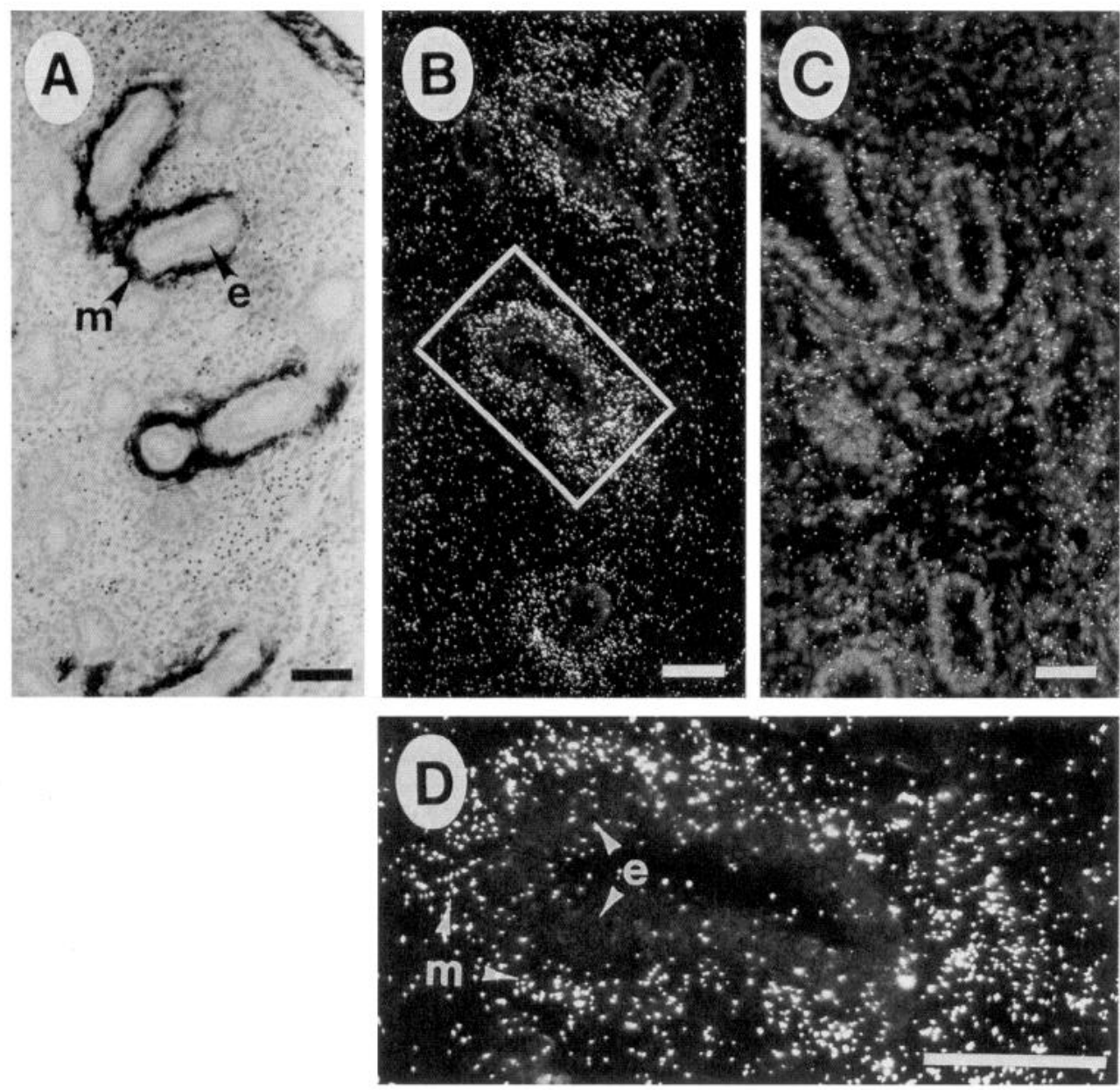

Figure 5. Localization of $\mathrm{p} 75^{\mathrm{NGFR}}$ in the mesenchymal cells surrounding the developing lung bronchioles at E16.5. $A$, Bright-field photomicrograph of p75 $5^{\text {NGFR }}$ immunoreactivity in mesenchymal cells $(m)$ surrounding the developing bronchiole epithelium $(e) . B$, Dark-field photomicrograph of section through E16.5 lung hybridized to antisense p $75^{\text {NGFr }}$ riboprobe. $C$, Dark-field photomicrograph of section adjacent to $B$ hybridized to antisense NGF riboprobe. $D$, Dark-field photomicrograph at higher magnification of bronchiole shown within boxed area in $B$. Note transcripts are confined to the mesenchymal cell populations $(m)$. Scale bars, $100 \mu \mathrm{m}$. servation of p75 $5^{\text {NGFR }}$ in developing muscle is in agreement with previous studies (Yan and Johnson, 1988) and is presented in Figure 9 . Figure $9 B$ shows p $75^{\text {NGFR }}$ immunoreactivity localized on the myoblast-like cells that lie adjacent to fused myotubes. By contrast, the myotubes were negative for $\mathrm{p} 75^{\mathrm{NGFR}}$. In situ hybridization analysis of adjacent sections of E18.5 forelimb show that $\mathrm{p} 75^{\text {NGFR }}$ transcripts (Fig. $9 \mathrm{C}$ ) were expressed in regions of developing muscle located adjacent to cells expressing NGF transcripts (Fig. 9D). This pattern of expression can be seen in developing muscle as early as E13.5, maximizes between E16.5 and E18.5, and declines by E21.5.

To characterize more clearly the myoblast-like cells expressing factor and receptor, sites of NGF and p $75^{\text {NGFR }}$ transcript synthesis were compared with those of MyoD1, a myoblast differentiation marker (Davis et al., 1987; Weintraub et al., 1989). In situ hybridization of adjacent sections of E16.5 and E18.5 embryos were hybridized with NGF, p75 ${ }^{\text {NGFR }}$, and MyoD1 antisense probes in order to localize $\mathrm{NGF}$ and $\mathrm{p} 75^{\mathrm{NGFR}}$ relative to myoblast cell populations. Figure 10 shows the expression of these molecules in the developing muscle surrounding the ribs in the E16.5 embryo and is representative of the patterns of expression we observed in the limbs and other regions of developing muscle. p75 ${ }^{\text {NGFR }}$ (Fig. $10 A, B$ ) was expressed in sites of developing muscle that also expressed MyoD1 transcripts (Fig. $10 D$ ). By contrast, NGF transcripts (Fig. 10C) were not colocalized in MyoD1-positive cells but were expressed in a cell population located adjacent to the developing myoblasts. There- fore, $\mathrm{p} 75^{\mathrm{NGFR}}$ transcription is most likely occurring in developing myoblasts and NGF is available from an adjacent cell population as a potential paracrine factor.

The expression of NGF and $\mathrm{p} 75^{\mathrm{NGFR}}$ in the developing muscle lead us to examine the myotome component of the developing somite to see if $\mathrm{p} 75^{\mathrm{NGFR}}$ or NGF is expressed in this early muscle precursor. Surprisingly, the myotome was negative for both NGF and $\mathrm{p} 75^{\mathrm{NGFR}}$. By contrast, we observed p $75^{\mathrm{NGFR}}$ expression at high levels in the sclerotome and expression of NGF transcripts in the adjacent dermatome (Fig. $11 \mathrm{~A}-\mathrm{C}$ ). NGF transcripts were also present in the sclerotome but at significantly lower levels than in the dermatome. We observed this pattern of expression in the somites from E12.5 through E14.5.

\section{Discussion}

The proposal that neuronal survival is critically influenced by NGF is well supported by data demonstrating its effect on sympathetic and sensory innervation (Greene and Shooter, 1980; Levi-Montalcini, 1987; Thoenen et al., 1987). These defined functions of NGF and p75 ${ }^{\text {NGFR }}$ on the nervous system are also important for innervation of target tissues during embryogenesis (Thoenen et al., 1987). However, recent studies describing the biological sites of NGF and $\mathrm{p} 75^{\mathrm{NGFR}}$ biosynthesis have revealed possible additional functions for this factor and its receptor during embryogenesis (Korsching and Thoenen, 1983; Heumann et al., 1984, 1987; Rush, 1984; Ebendal et al., 1985; Finn et al., 1986; Shelton and Reichardt, 1986; Buck et al., 1987; 

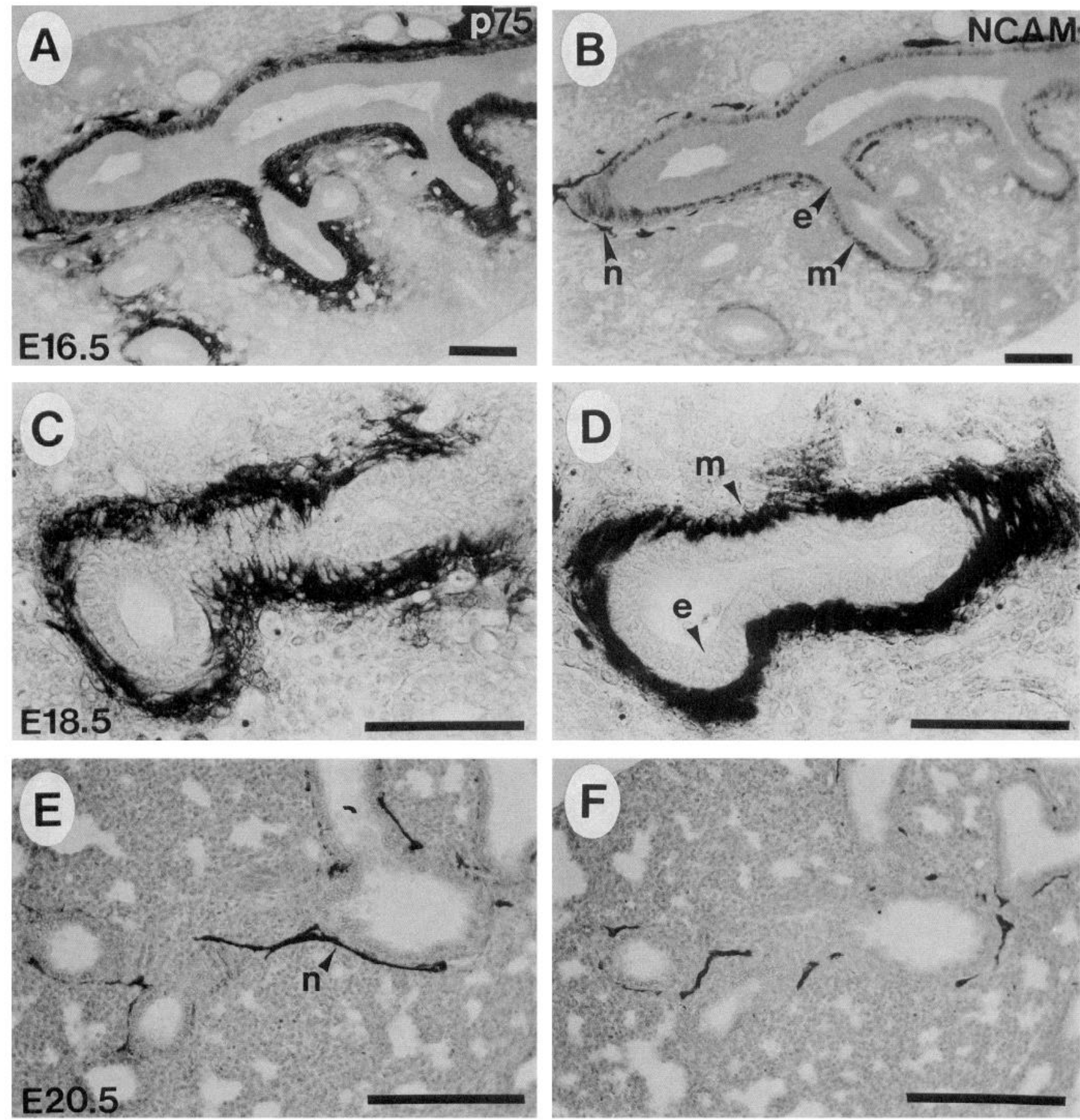

Figure 6. p75 ${ }^{\text {NGFR }}$ and NCAM immunoreactivity in the nerve fibers and mesenchymal cells surrounding the lung bronchioles at E16.5, E18.5, and E20.5. A, Bright-field photomicrograph of p75 ${ }^{\mathrm{NGFR}}$-immunoreactive mesenchyme surrounding the lung bronchioles at E16.5. B, NCAM immunoreactivity in section adjacent to $A$. Note patterns of NCAM expression in the bronchiole mesenchyme $(m)$ are localized to areas of p75 ${ }^{\text {NOFR }}$ in $A$. Note also the nerve fiber $(n)$ ingrowth is confined to the bronchiole mesenchyme. $C$, Bright-field photomicrograph of p75 NGFR immunoreactivity in the mesenchyme surrounding the bronchiole of an E18.5 embryo. $D$, NCAM immunoreactivity in section adjacent to $C$. Note the similarity in patterns of expression p $75^{\text {NGFR }}$ and NCAM in the bronchiole mesenchyme $(m)$ at this stage. $E$, Bright-field photomicrograph of p75 NGFR immunoreactivity in the nerve fibers $(n)$ surrounding the bronchioles at E20.5. $F$, Bright-field photomicrograph of NCAM immunoreactivity in the section adjacent to $E$. Note both molecules clearly mark sites of innervation. $e$, epithelium. Scale bars, $100 \mu \mathrm{m}$.

Davies et al., 1987a; Ayer-LeLivre et al., 1988; Rohrer et al., 1988; Yan and Johnson, 1988; Ernfors et al., 1990; Senut et al., 1990). The variety of non-neuronal cells that express NGF and p $75^{\text {NGFR }}$ have until now been described in terms of the trophic mechanisms that direct and modulate innervation of target tis- sue (Davies et al., 1987a; Levi-Montalcini, 1987; Wyatt et al., 1990). However, when we examined a broad range of developing tissues, we did not see a consistent correlation between the levels of NGF and p75 $5^{\mathrm{NGFR}}$ expression and the degree of innervation in a given target tissue. Rather, the results we report here show 

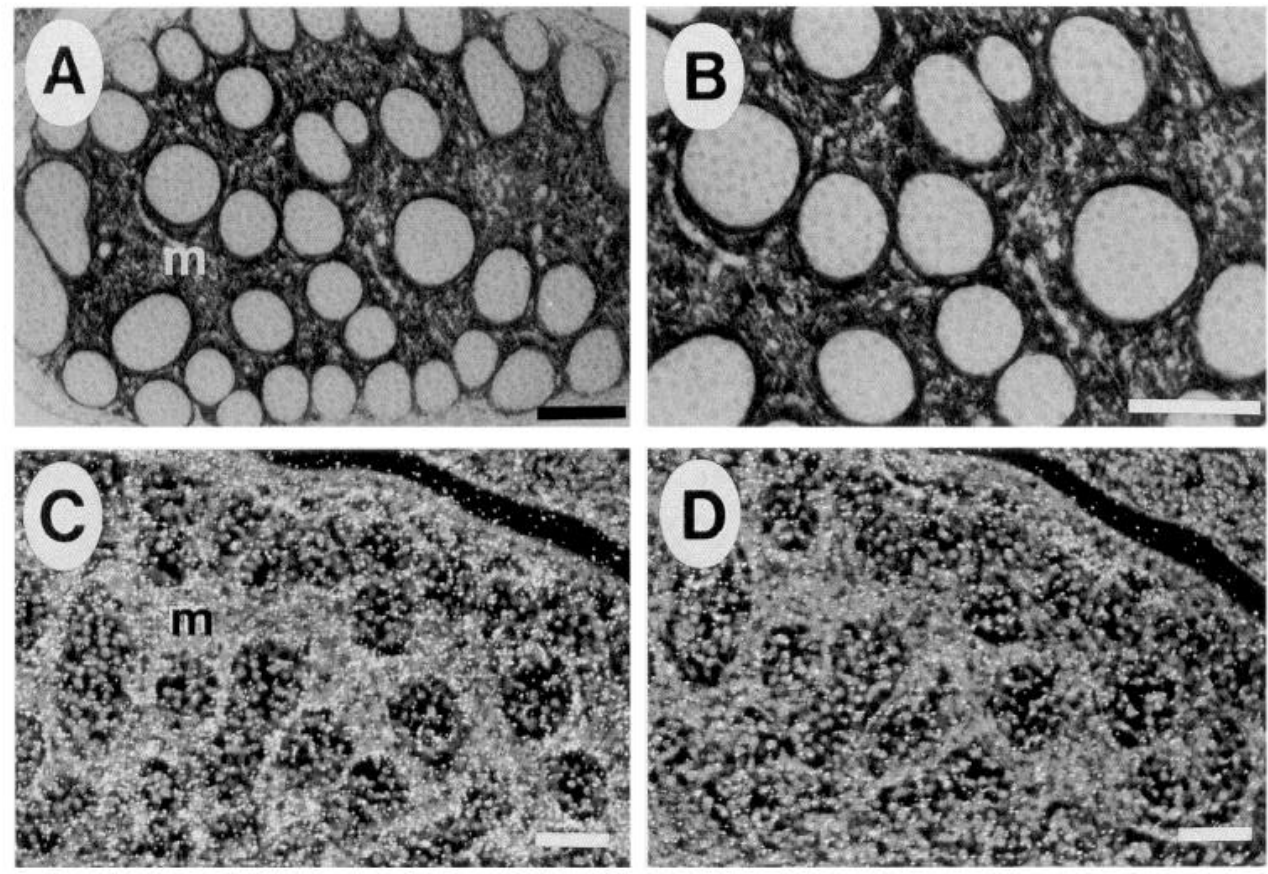

Figure 7. Expression of $75^{\text {NGFR }}$ in the developing rat testes. $A$, Bright-field photomicrograph of section through rat testes immunostained with monoclonal antibody $192-\mathrm{IgG}$ against p75 ${ }^{\mathrm{NGFR}}$. Note the immunoreactivity is confined to the mesenchyme $(m)$ surrounding the epithelia of the developing seminiferous tubules. $B$, Higher magnification of $A$. $C$, Dark-field photomicrograph of section through the testes hybridized to antisense p $75^{\mathrm{NGFR}}$ riboprobe. Note transcripts are confined to the mesenchyme $(m) . D$, Dark-field photomicrograph of section adjacent to $F$ and hybridized to antisense NGF riboprobe. Note the absence of transcripts. Scale bars, $100 \mu \mathrm{m}$. that the synthesis of NGF and p75 NGFR also correlates spatially and temporally with the development of specific cell types already known to play critical roles in pattern formation, inductive tissue interactions, and myogenesis.

\section{Comparison of NGF and $p 75^{N G F R}$ expression in the limb and maxilla}

Although NGF and p75 NGFR expression in the maxillary pad correlates well with NGF-mediated neurotrophic regulation (Davies et al., 1987a; Wyatt et al., 1990), both NGF and p75 $5^{\text {NGFR }}$ were expressed to a comparable extent in the epithelia at the limb axilla and other axillary points that are not as highly innervated as the maxillary pad. Interestingly, the sites of NGF and $\mathrm{p} 75^{\mathrm{NGFR}}$ transcript expression at the limb axilla are localized in or near tissue regions that mediate limb extension. NGF and p $75^{\text {NGFR }}$ were most abundantly expressed at the proximal/distal sites of the deyeloping limb from the onset of limb bud formation to the latest stages of gestation. In the chick, the extension of the developing limb has been shown to occur in a proximal-to-distal direction (Saunders and Gassling, 1968; Fallon et al., 1983). This process is mediated by the apical ectodermal ridge located at the distal end of the limb bud and the zone of polarizing activity at the proximal end of the limb close to the axillary junctions. These specialized embryonic structures are derived from the mesoderm and have been shown to have roles in regulating limb extension in conjunction with the mesenchymal regions of the limb axilla. The colocalization of NGF and p $75^{\text {NGFR }}$ at these inductive sites suggests that they are involved in this process. Whether or not these molecules mediate a specific morphogenic function or serve to integrate innervation with morphogenesis remains to be determined.

In addition to the extensive coordinate expression of NGF and p75 $5^{\text {NGFR }}$ in developing skin, there also appears to be coordination between expression of NGF transcripts in the epithelial and mesenchymal components of skin. While the levels of NGF mRNA in various regions of developing skin are quite variable, where levels of NGF mRNA are relatively high in the epithe- lium, there are also relatively high levels in the subjacent mesenchyme. The functional significance of expression of NGF by both epithelial and mesenchymal cells is unclear. The two sources of NGF might be functionally equivalent. Alternatively, they might have distinct functions. For example, NGF produced by epithelial cells may primarily provide trophic support to sensory neurons while NGF produced by mesenchymal cells may influence p $75^{\text {NGFR }}$-positive mesenchymal cells in an autocrine fashion. Such questions cannot be addressed experimentally unless means can be developed to block NGF expression in a cell typespecific manner.

\section{p7 $5^{\text {NGFR }}$ expression during organogenesis of the lung, testes, and kidney}

While NGF and p75 NGFR expression colocalizes in the mesenchyme of the developing skin, p75 ${ }^{\text {NGFR }}$ expression occurs in the absence of detectable NGF expression in other tissues such as the lung, testes, and kidney. The lack of NGF transcripts in these organs was observed in the same tissue sections that showed strong signals for NGF in the skin and muscle. Therefore, if NGF was present in the organ sections we analyzed, it was at relatively low levels. Expression of the receptor accompanies the development of the bronchiole airways and the trachea, initiating in the trachea at E14.5, a time that precedes innervation of the lung. p75 $5^{\mathrm{NGFR}}$ expression peaks in the bronchiole mesenchymal cells at E17.5, a time when the bronchioles are undergoing extensive innervation, and ceases by E18.5, a time when lung bronchiole morphogenesis has neared completion. Interestingly, p75 $5^{\mathrm{NGFR}}$ expression in the lung occurred in the areas that became innervated, suggesting this molecule has a role in that process. However, $\mathrm{p} 75^{\mathrm{NGFR}}$ expression also correlates extremely well with the pattern of NCAM expression in the bronchiole mesenchyme. NCAM and p $75^{\text {NGFR }}$ expression appears to occur in identical subpopulations of mesenchymal cells surrounding the developing bronchioles, suggesting the function of these molecules may also be coordinately linked to bronchiole morphogenesis. 


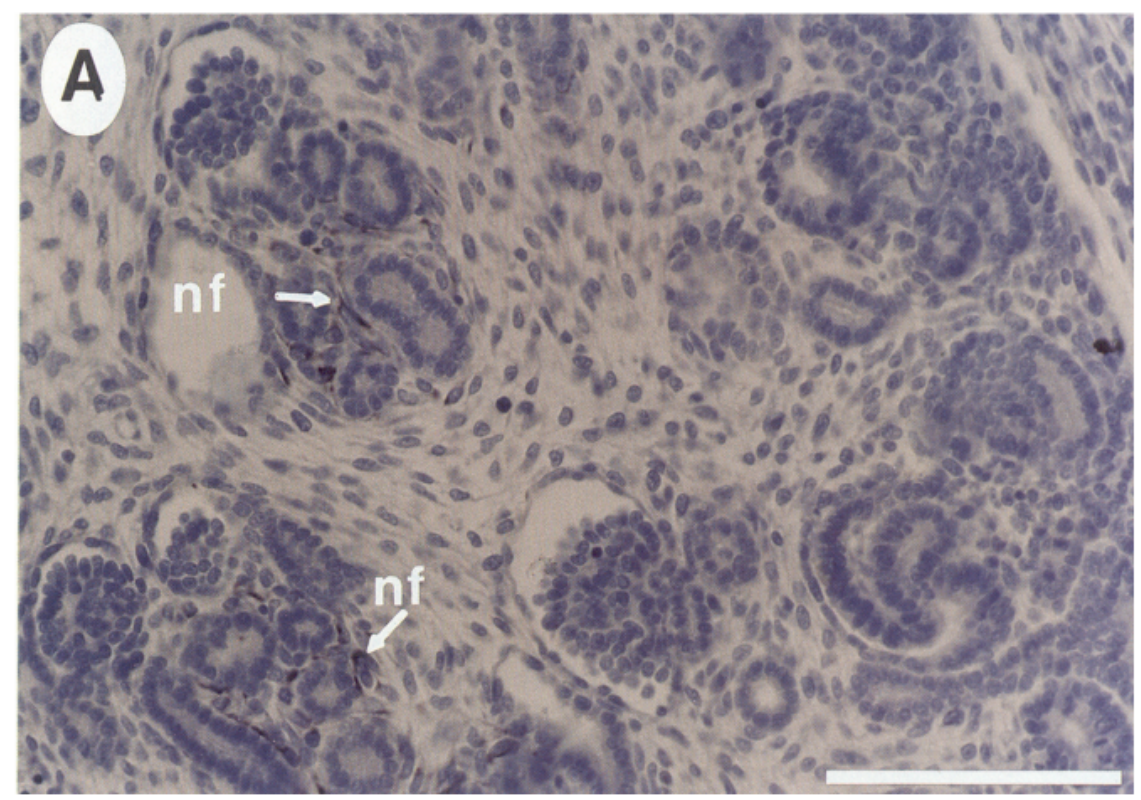

Figure 8. Innervation and NCAM expression of the kidney glomeruli relative to $\mathrm{p} 75^{\text {NGFR }}$ expression. $A$, Brightfield photomicrograph of neurofilament (nf) immunoreactivity of the kidney at E18.5. Note staining is confined to tubules. Glomeruli are negative. $B$, p75 NGFR immunoreactivity in section adjacent to $A$. Note immunoreactivity is confined to the glomeruli $(g l)$. $C$, NCAM immunoreactivity in section adjacent to $B$. Note similarity between p75 ${ }^{\text {NGFR }}$ and NCAM expression in the glomeruli $(g l) . t$, tubule. Scale bars, 50
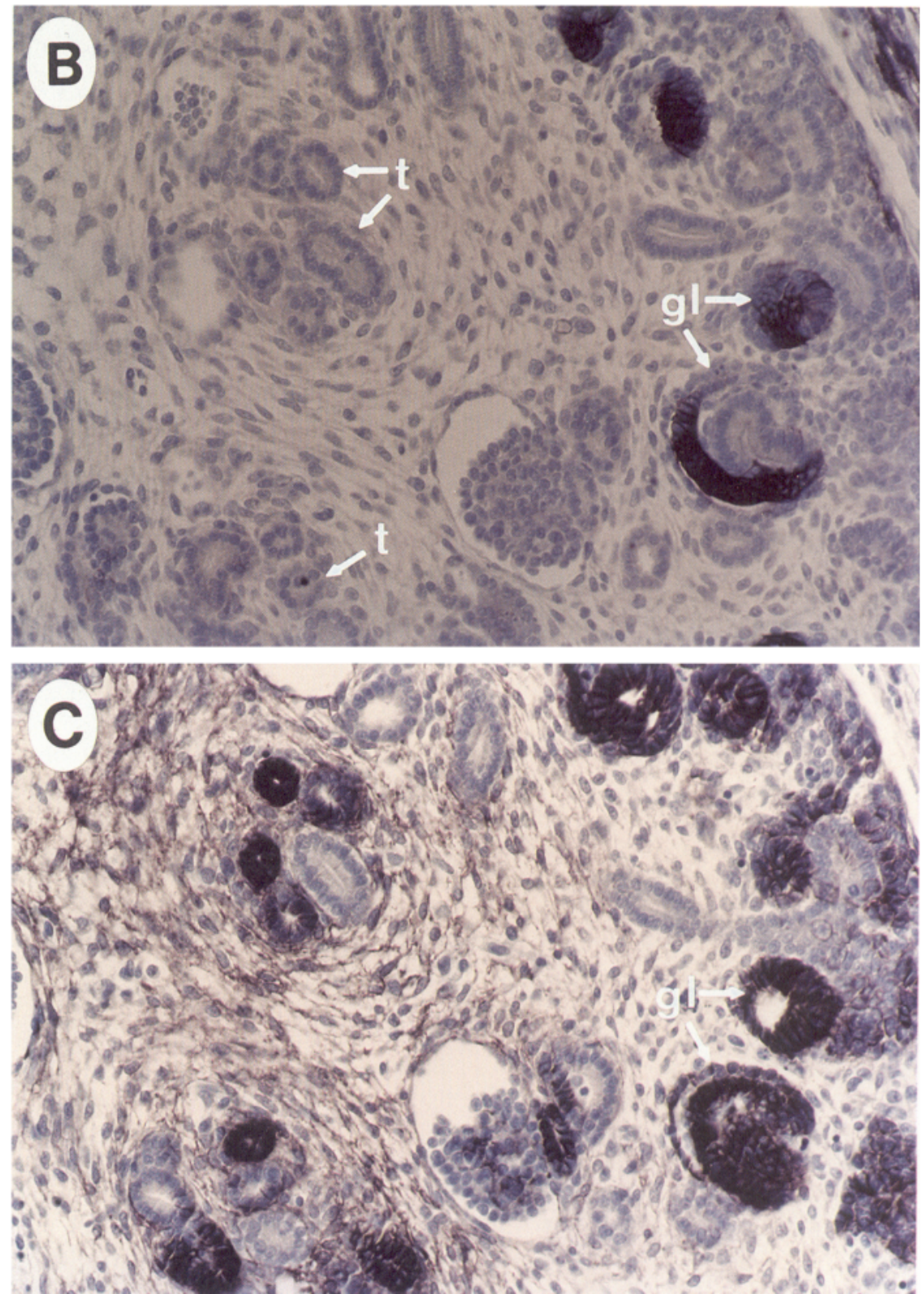
$\mu \mathrm{m}$. 

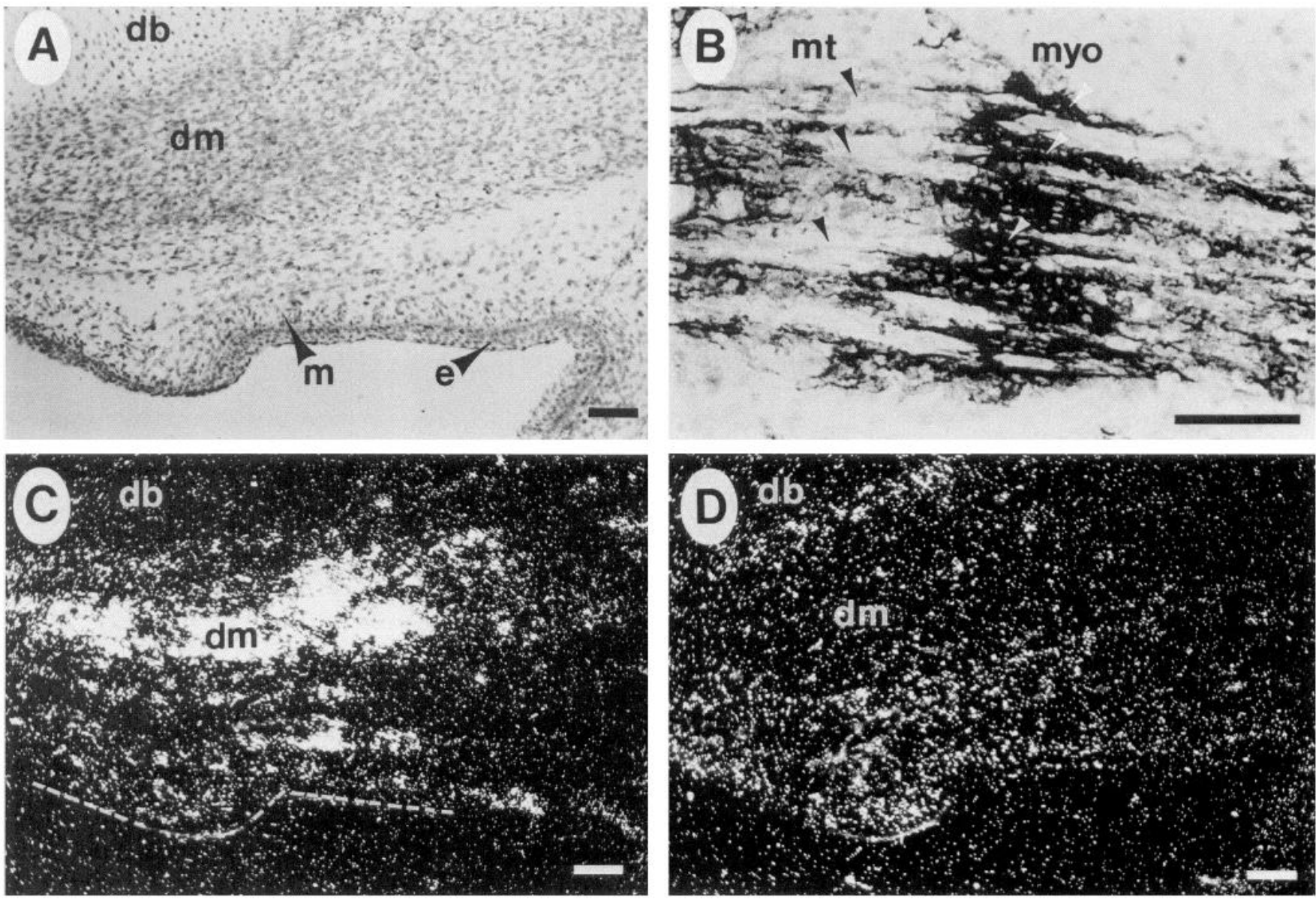

Figure 9. NGF and p75 NGFR expression in the developing forelimb muscle at E18.5. A, Bright-field photomicrograph of hematoxylin and eosinstained section through the muscle of an E18.5 forelimb. $B$, Bright-field photomicrograph at high magnification of developing muscle fibers immunoreacted with monoclonal antibody against rat p $75^{\mathrm{NGFR}}$. Note myotubes $(\mathrm{mt})$ are negative (solid arrowheads) while myoblast-like cells $(\mathrm{myo})$ are positive (open arrowheads) for p75 NGFR immunoreactivity. $C$, Dark-field photomicrograph of section adjacent to $A$ and hybridized to antisense p75 $5^{\text {NGFR }}$ riboprobes. Note high levels of transcript localized in regions of developing muscle $(\mathrm{dm})$. $D$, Dark-field photomicrograph of section adjacent to $C$ and hybridized to antisense NGF riboprobes. Note NGF-positive cells localized adjacent to p $75^{\text {NGFR }}$-positive cells. $d b$, developing bone; $e$, epithelium; $m$, mesenchyme. Scale bars: $A, C$, and $D, 200 \mu \mathrm{m} ; B, 100 \mu \mathrm{m}$.

Patterns of expression of $\mathrm{p} 75^{\mathrm{NGFR}}$ in the testes were very similar to those of the lung in that expression occurred in the mesenchymal cells that surround the epithelia of the developing seminiferous tubules. By contrast, coexpression of NCAM and p $75^{\text {NGFR }}$ in the testes occurred in mesenchymal cell populations surrounding the tubules at a later stage of development than in the lung. In both the lung and testes, NCAM expression commenced in late stages of morphogenesis, suggesting that $\mathrm{p} 75^{\mathrm{NGFR}}$ and NCAM may have early and late functional roles in the development of these epithelial structures.

It is well established that both the kidney and the testes are innervated from the aortic and renal plexus with vasomotor and afferent nerve fibers that are associated with the vasculature of those organs (Mitchell, 1935; Tisher, 1981; Geneser, 1986). The seminiferous tubules are not innervated, and the surrounding interstitial tissue contains very few nerve fibers. Similarly, the kidney glomeruli do not become innervated. Although p $75^{\text {NGFR }}$ expression in the kidney occurred in a different cell type, the patterns of p $75^{\text {NGFR }}$ and NCAM expression are similar to that of the lung and testes mesenchyme. The polarizing epithelia that form the glomuleri are strongly p $75^{\mathrm{NGFR}}$ positive during morphogenesis and coexpress high levels of NCAM (Lackie et al.,
1990). Therefore, $p 75^{\text {NGFR }}$ expression in the testes and kidney appears to be more closely associated with the expression of cell adhesion molecules and the epithelial morphogenesis than innervation. This coexpression of $\mathrm{p} 75^{\mathrm{NGFR}}$ and NCAM described here for the kidney, lung, and testes is typical of widespread coexpression of these proteins observed in many developing tissues (E. F. Wheeler and M. Bothwell, unpublished observations).

Although we were not able to observe NGF transcripts in the mesenchymal cells of the lung and testes or the kidney glomeruli, we cannot exclude the possibility that the levels of NGF transcripts were too low to detect with our assay system. This may be true in particular for the testes since NGF has been reported to be expressed in the adult rat testes (Ayer-LeLievre et al., 1988; Persson et al., 1990). However, it is also possible that p75 ${ }^{\text {NGFR }}$ is responding to a different ligand in these cells. Recently, two structural homologs of NGF, BDNF and NT-3 (Leibrock et al., 1989; Hohn et al., 1990; Maisonpierre et al., 1990), have been shown to bind to $\mathrm{p} 75^{\mathrm{NGFR}}$ with affinities comparable to that of NGF (Hohn et al., 1990; Rodriguez-Tebar et al., 1990). These investigators proposed that the low-affinity component of the NGF receptor interacts with a second protein (or set of 

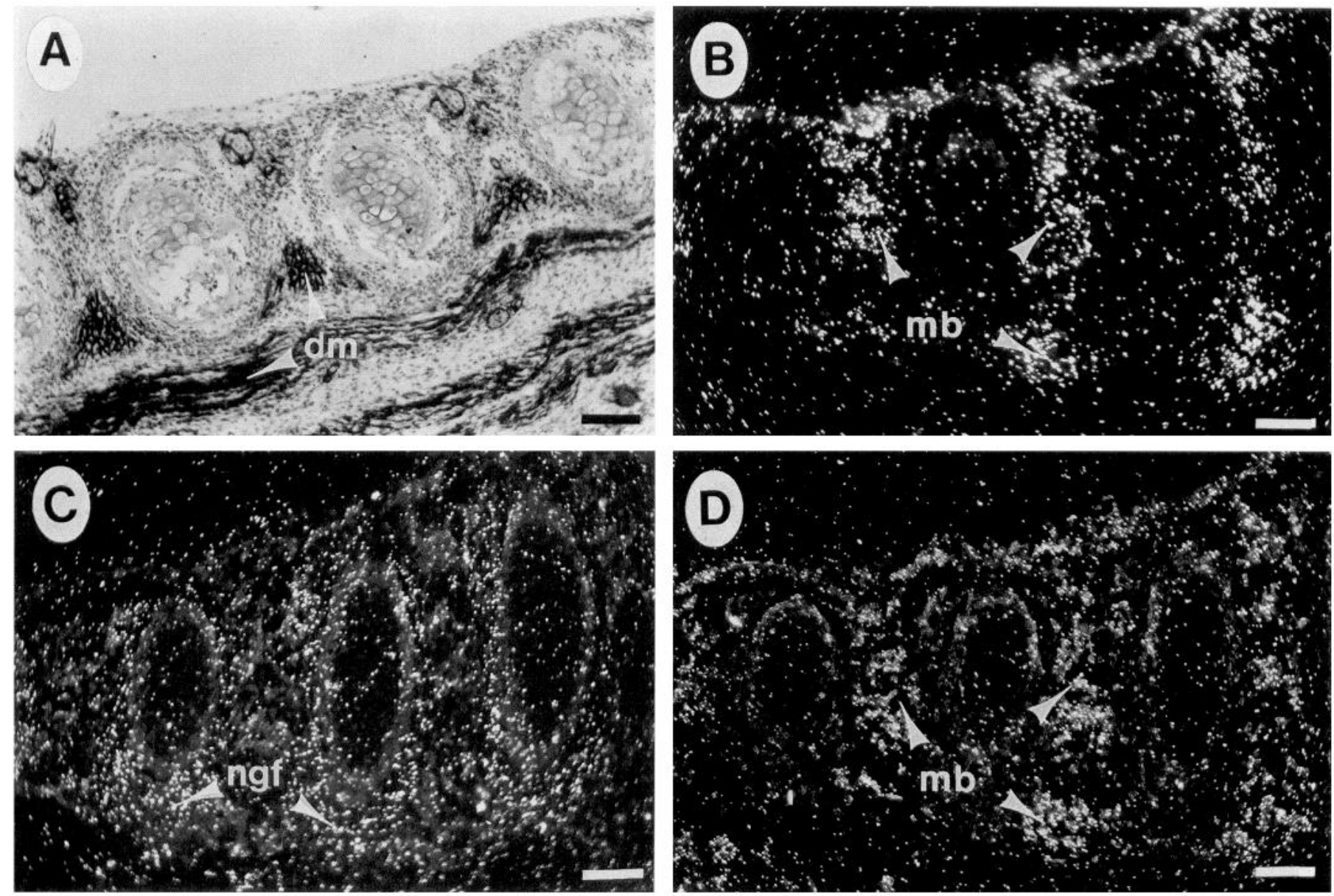

Figure 10. Sites of NGF and p75 $5^{\mathrm{NGFR}}$ transcripts expression relative to that of MyoD1 transcripts in developing muscle at E16.5. A, Bright-field photomicrograph of section through developing rib muscle $(\mathrm{dm})$ immunoreacted with monoclonal antibody 192 -IgG against rat p75NGFR. $B$, Darkfield photomicrograph of section (adjacent to $D$ ) through developing rib muscle hybridized to anti-sense p75NGFR riboprobe. $C$, Dark-field photomicrograph of section (adjacent to $D$ ) through developing rib muscle hybridized to antisense NGF (ngf) riboprobe. $D$, Dark-field photomicrograph of section adjacent to $B$ and $C$ and hybridized with antisense MyoD1 riboprobe. Note MyoD1 transcripts colocalize with p75 whereas NGF transcripts localize to adjacent cells. $m b$, myoblasts. Scale bars, $100 \mu \mathrm{m}$.

proteins) to form the high-affinity form of the receptor. This ancillary protein(s) would presumably be tissue specific and determine the ligand specificity of the high-affinity receptor.

The $t r k A$ protooncogene product apparently corresponds to the postulated ancillary protein for the NGF receptor (Kaplan et al., 1991). The trkA gene is a member of a multigene family encoding a set of proteins characterized by a membrane-spanning tyrosine kinase that bear similarities to the receptors for a variety of other growth factors (Klein et al., 1989; Martin-Zanca et al., 1989; Middlemas et al., 1991). Recent evidence indicates that the trk family encodes receptors that bind to and mediate signals for the other neurotrophins (Cordon-Cardo et al., 1991; Klein et al., 1991). Like the NGF receptors, the BDNF and NT3 receptors have both low- and high-affinity forms (Sutter et al., 1979; Rodriguez-Tebar et al., 1990), and expression of the highaffinity receptors appears to be essential for biological responses to these ligands. Since the low-affinity NGF receptor, p $75^{\text {NGFR }}$, will bind to both BDNF and NT3 with affinities comparable to that of NGF (Ernfors et al., 1990; Rodriguez-Tebar et al., 1990), the p75 $5^{\text {NGFR }}$ cDNA that we have used (Radeke et al., 1987) may encode a common subunit of a class of multimeric neurotrophin receptors (Berg et al., 1991; Bothwell, 1991; Hempstead et al.,
1991). Therefore, the possibility that $p 75^{\text {NGFR }}$ is responding to an NGF-related ligand in these developing organs cannot be excluded and is strongly supported by expression of NT3 in the kidney glomeruli and ovary (Ernfors et al., 1990).

\section{$p 75^{\text {NGFR }}, N G F$, and myogenesis}

Several investigators have noted the expression of p $75^{\text {NGFR }}$ in developing muscle (Ernfors et al., 1988; Yan and Johnson, 1988; Heuer et al., 1990). However, the phenotype of the p $75^{\text {NGFr }}$ positive cells has not been characterized and no attempt has been made to address whether NGF may be available to those cells. We found that the expression of NGF and p $75^{\text {NGFR }}$ transcripts in the developing muscle differs from that of the epithelial/mesenchymal systems in that NGF appears to be available to $\mathrm{p} 75^{\mathrm{NGFR}}$-positive cells from a paracrine source. The fact that transcripts for MyoD1 localized in the same regions of developing muscle that were $\mathrm{p} 75^{\mathrm{NGFR}}$ positive strongly suggests that p $75^{\text {NGFR }}$ is expressed in developing myoblasts. Although we have not yet characterized the cells expressing NGF transcripts, they clearly develop in regions adjacent to myoblasts that express p $75^{\text {NGFR }}$. Both NGF- and p $75^{\text {NGFR }}$-positive cells are present during myoblast differentiation and cease to be expressed when the 

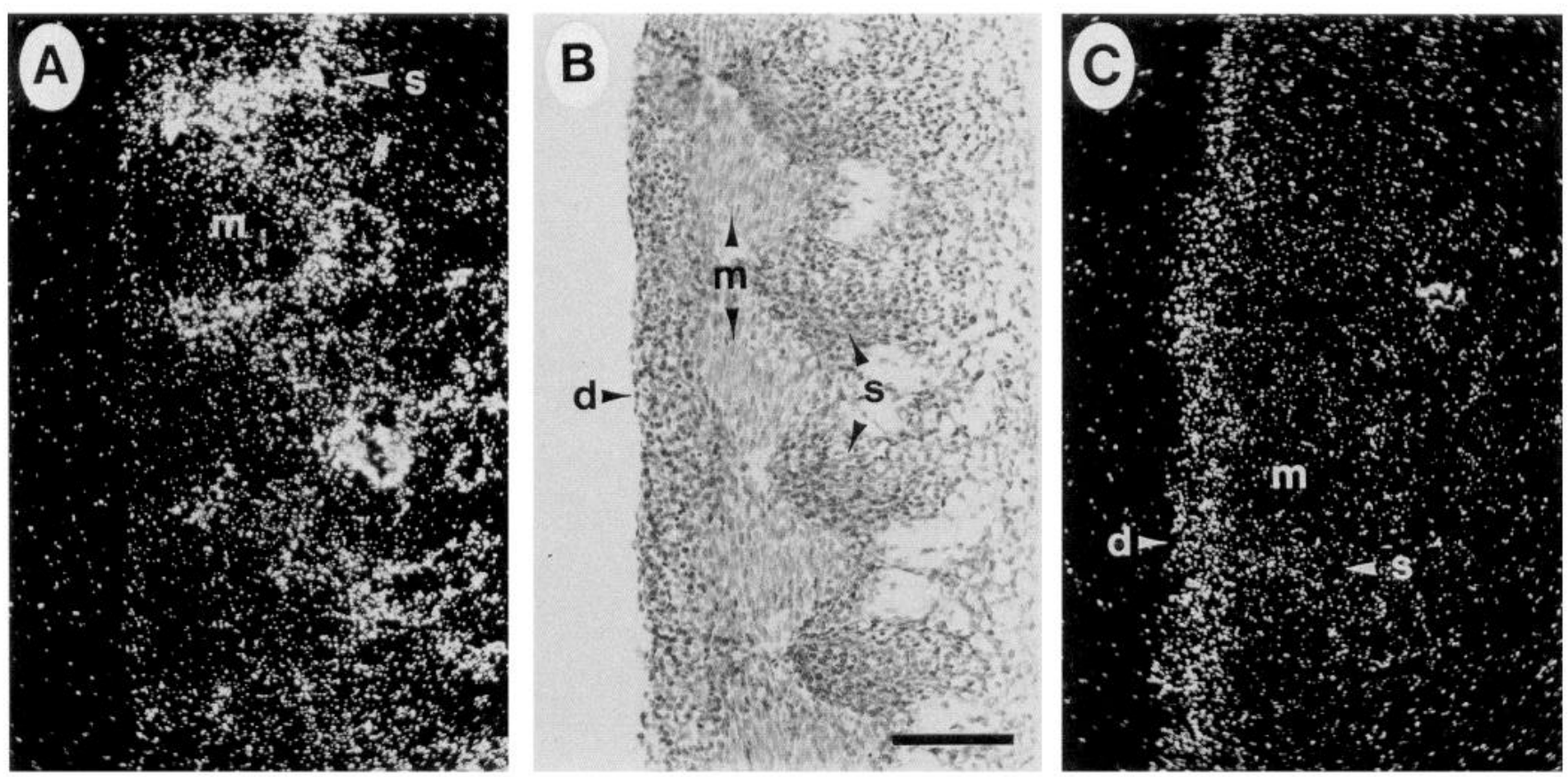

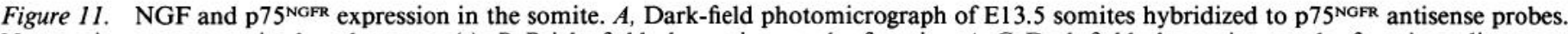
Note grains are present in the sclerotome $(s)$. $B$, Bright-field photomicrograph of section $A$. $C$, Dark-field photomicrograph of section adjacent to $A$. Section was hybridized with NGF antisense probe. Note grains are localized in the dermatome $(d)$ and are present at low levels in the sclerotome (s). $m$, myotome. Scale bars, $100 \mu \mathrm{m}$.

myoblasts fuse to form myotubes. These data are not easy to correlate with the innervation of developing muscle. Neither motor nor proprioceptive sensory innervation is influenced by NGF (Thoenen and Barde, 1980; Davies et al., 1987b; Yan et al., 1988; Oppenheim, 1989). Therefore, the NGF synthesized by the cells adjacent to developing muscle may serve as a paracrine factor for the p $75^{\text {NGFr }}$-positive myoblasts. This notion is supported by data that suggest an NGF influence on the expression of sodium channels during the differentiation of muscle cells (Brodie and Sampson, 1990).

Although NGF and p $75^{\mathrm{NGFR}}$ appear to play a role in muscle development, neither molecule was expressed by the myotome. Rather, the dermatome and the sclerotome were observed to express NGF and p $75^{\text {NGFR }}$, respectively. Both the dermatome and sclerotome differentiate into connective tissue components, the dermatome into the dermis and the sclerotome into skeletal tissue. The expression of NGF and p $75^{\mathrm{NGFR}}$ in dermatome and sclerotome occurs prior to cellular differentiation and precedes the onset of innervation of these tissues. The timing of expression suggests that the functional role of NGF and $\mathrm{p} 75^{\mathrm{NGFR}}$ in these developing tissues may involve processes separate from neural development.

\section{Conclusion}

Taken together, these results raise new questions about the function of NGF and its low-affinity receptor in the developing embryo. The well-characterized trophic functions of these molecules clearly effect important developmental neuronal processes. However, the expression of NGF and p $75^{\mathrm{NGFR}}$ during the morphogenesis of the limb and the organs described in this study suggests that NGF and $p 75^{\text {NGFR }}$ may have other activities that affect the development of non-neuronal tissues. The expression of these molecules in mesenchymal cells that have been defined as having "instructive" roles in determining the development of these embryonic systems suggests functions apart from regulation of innervation. In addition, NGF and p75 $5^{\text {NGFR }}$ appear to be involved in the process of myogenesis. It will be important to determine whether or not the $t r k$ family of protooncogenes is coordinately expressed with NGF and p $75^{\mathrm{NGFR}}$. Since the tyrosine-specific kinases have well-documented effects on cell proliferation and differentiation (Knochel and Tiedemann, 1989), it would not be surprising to find correlations between the expression of the trk protooncogenes, p $75^{\mathrm{NGFR}}$, and neurotrophins during these developmental events.

Although p $75^{\text {NGFR }}$ expression frequently correlates with morphogenic processes in which innervation does not play a part, there are many instances in which there is an extensive correlation between sites of $p 75^{\text {NGFR }}$ expression and patterns of innervation that cannot be ignored. The maxillary pad and the lung are obvious examples. Perhaps p $75^{\text {NGFR }}$ and its interactive ligands, NGF, BDNF and NT3, are involved in a multifunctional regulatory system that serves to integrate morphogenesis and myogenesis with innervation. The manner in which mesenchymal cell function is regulated by this system is unclear. However, the fact that $\mathrm{p} 75^{\mathrm{NGFR}}$ is extensively coexpressed with the cell adhesion molecule NCAM, which itself is implicated in both neural development and the morphogenesis of non-neural tissues, is an important clue that may provide a direction for future studies.

\section{References}

Angerer LM, Stoler MH, Angerer RC (1987) In situ hybridization with RNA probes: an annotated recipe. In: In situ hybridization: applications to neurobiology (Valentino K, Eberwine J, Barohas J, eds), pp 42-70. New York: Oxford UP.

Ayer-LeLievre C, Olson L, Ebendal T, Hallböök F, Persson H (1988) 
Nerve growth factor mRNA and protein in the testis and epididymis of mouse and rat. Proc Natl Acad Sci USA 85:2628-2632.

Berg MM, Sternberg DW, Hempstead BL, Chao MV (1991) The lowaffinity p75 nerve growth factor (NGF) receptor mediates NGF-induced tyrosine phosphorylation. Proc Natl Acad Sci USA 88:71067110.

Bothwell M (1991) Keeping track of neurotrophin receptors. Cell 65: 915-918.

Brodie C, Sampson SR (1990) Nerve growth factor and fibroblast growth factor influence post-fusion expression of $\mathrm{Na}$-channels in cultured rat skeletal muscle. J Cell Physiol 144:492-497.

Buck CR, Martinez HJ, Black IB, Chao MV (1987) Developmentally regulated expression of the nerve growth factor receptor gene in the periphery and brain. Proc Natl Acad Sci USA 84:3060-3063.

Byers MR, Schatteman GC, Bothwell M (1990) Multiple functions for NGF receplor in developing, aging and injured rat teeth are suggested by epithelial, mesenchymal and neural immunoreactivity. Development 109:461-471.

Chandler CE, Parsons LM, Hosang M, Shooter EM (1984) A monoclonal antibody modulates the interaction of nerve growth factor with PC12 cells. J Biol Chem 259:6882-6889.

Cordon-Cardo C, Tapley P, Jing S, Nanduri V, O'Rourke E, Lamballe F, Kovary K, Klein R, Jones KR, Reichardt LF, Barbacid M (1991) The trk tyrosine protein kinase mediates the mitogenic properties of nerve growth factor and neurotrophin-3. Cell 66:173-183.

Cox KH, DeLeon DV, Angerer LM, Angerer RC (1984) Detection of mRN $\Lambda$ s in sea urchin embryos by in situ hybridization using asymmetric RNA probes. Dev Biol 101:485-502.

Davies AM, Bandtlow C, Heumann R, Korsching S, Rohrer H, Thoenen H (1987a) Timing and site of nerve growth factor synthesis in developing skin in relation to innervation and expression of the receptor. Nature 326:353-357.

Davies AM, Lumsden AGS, Rohrer H (1987b) Neural crest-derived proprioceptive neurons express nerve growth factor receptors but are not supported by nerve growth factor in culture. Neuroscience 20 : $37-46$.

Davis RL, Weintraub $\mathrm{H}$, Lasson $\mathrm{AB}$ (1987) Expression of a single transfected cDNA converts fibroblasts to myoblasts. Cell 51:9871000 .

Ebendal T, Larkfors L, Ayer-LeLievre C, Seiger A, Olson L (1985) New approaches to detect NGF-like activity in tissues. In: Hormones and cell regulation, Vol 9 (Dumont JE, Hamprecht B, Nuney J, eds), pp 361-375. Amsterdam: Elsevier.

Edelman GM (1984) Modulation of cell adhesion during induction, histogenesis, and perinatal development of the nervous system. Annu Rev Neurosci 7:339-377.

Ernfors P, Hallböök F, Ebendal T, Shooter EM, Radeke MJ, Misko TP, Persson H (1988) Developmental and regional expression of betanerve growth factor receptor mRNA in chick and rat. Neuron 1:983996.

Ernfors P, Wetmore C, Olson L, Persson H (1990) Identification of cells in rat brain and peripheral tissues expressing mRNA for members of the nerve growth factor family. Neuron 5:511-526.

Fahnestock M, Bell RA (1988) Molecular cloning of a cDNA encoding the nerve growth factor precursor from Mastomys natalensis. Gene 69:257-264.

Fallon JF, Rowe DA, Frederick JM, Simandl BK (1983) Studies on epithelial-mesenchymal interactions during limb development. In: Epithelial-mesenchymal interactions in development (Sawyer RH, Fallon JF, eds), pp 3-24. New York: Praeger Scientific.

Finn PJ, Ferguson IA, Renton FJ, Rush RA (1986) Nerve growth factor immunohistochemistry and biological activity in the rat iris. $J$ Neurocytol 15:169-176.

Geneser F (1986) The male reproductive system. In: Textbook of anatomy, pp 618-648. Philadelphia: Lea and Febiger.

Greene LA, Shooter EM (1980) The nerve growth factor: biochemistry, synthesis, and mechanism of action. Annu Rev Neurosci 3:353-402.

Hallböök F, Ayer-LeLievre C, Ebendal T, Persson H (1990) Expression of nerve growth factor receptor mRNA during early development of the chicken embryo: emphasis on cranial ganglia. Development 108:693-704.

Hempstead BL, Martin-Zanco D, Kaplan DR, Parada LF, Chao MV (1991) High affinity NGF binding requires co-expression of the $t r k$ protooncogene and the low affinity NGF receptor. Nature 350:675683.
Heuer JG, Fatemie-Nainie S, Wheeler EF, Bothwell M (1990) Structure and developmental expression of the chicken NGF receptor. Dev Biol 137:287-304.

Heumann R, Korsching S, Scott J, Thoenen H (1984) Relationship between levels of nerve growth factor (NGF) and its messenger RNA in sympathetic ganglia and peripheral target tissues. EMBO J 3:31383189.

Heumann R, Korsching S, Bandtlow C, Thoenen H (1987) Changes of nerve growth factor synthesis in non-neuronal cells in response to sciatic nerve transection. J Cell Biol 104:1623-1631.

Hilfer SR, Rayner RM, Brown JW (1985) Mesenchymal control of branching pattern in the fetal mouse lung. Tissue Cell 17:523-537.

Hohn A, Leibrock J, Bailey K, Barde Y-A (1990) Identification and characterization of a novel member of the nerve growth factor/brainderived neurotrophic factor family. Nature 344:339-341.

Johnson EM Jr, Taniuchi M, DiStefano PS (1988) Expression and possible function of nerve growth factor receptors on Schwann cells. Trends Neurosci 11:299-304.

Kaplan DR, Dionisio M, Parada LF (1991) Tyrosine phosphorylation and tyrosine kinase activity of the trk proto-oncogene product induced by NGF. Nature 350:158-161.

Klein R, Parada LF, Coulier F, Barbacid M (1989) trk B, a novel tyrosine protein kinase receptor expressed during mouse neural development. EMBO J 8:3701-3709.

Klein R, Nanduri V, Jing S, Lamballe F, Tapley P, Bryant S, CordonCardo C, Jones KR, Reichardt LF, Barbacid M (1991) The trk B tyrosine protein kinase is a receptor for brain-derived neurotrophic factor and neurotrophin-3. Cell 66:395-403.

Knochel W, Tiedemann H (1989) Embryonic inducers, growth factors, Iranscription factors and oncogenes. Cell Differ Dev 26:163-171.

Korsching S, Thoenen H (1983) Developmental changes of nerve growth factor levels in sympathetic ganglia and their target organs. Dev Biol 126:40-46.

Lackie PM, Zuber C, Roth J (1990) Polysialic acid and N-CAM localization in embryonic rat kidney: mesenchymal and epithelial elements show different patterns of expression. Development 110:933947.

Leibrock J, Lottspeich F, Hohn A, Hofer M, Hengerer B, Masiakowski P, Thoenen H, Barde Y-A (1989) Molecular cloning and expression of brain-derived neurotrophic factor. Nature 341:149-152.

Levi-Montalcini R (1987) The nerve growth factor: thirty five years later. EMBO J 6:1145-1154.

Maisonpierre PC, Belluscio L, Squinto S, Ip NY, Furth ME, Lindsay RM, Yancopoulos GD (1990) Neurotrophin-3: a neurotrophic factor related to NGF and BDNF. Science 247:1446-1451.

Martin-Zanca D, Oskam R, Mitra G, Copeland T, Barbacid M (1989) Molecular and biochemical characterization of the human trk protooncogene. Mol Cell Biol 9:24-33.

Melton DA, Krieg PA, Rebagliati MR, Maniatis T, Zinn K, Green MR (1984) Efficient in vitro synthesis of biologically active RNA and RNA hybridization probes from plasmids containing a bacteriophage SP6 promotor. Nucleic Acids Res 12:7035-7056.

Middlemas DS, Lindberg RA, Humter T (1991) trkB, a neural receptor protein-tyrosine kinase: evidence for a full-length and two truncated receptors. Mol Cell Biol 11:143-153.

Mitchell MB (1935) The innervation of the kidney, ureter, testicle and epididymis. J Anat 70:10-32.

Oppenheim RW (1989) The neurotrophic theory and naturally occurring motorneuron death. Trends Neurosci 12:252-255.

Persson H, Ayer-LeLievre C, Soder O, Villar MJ, Metsis M, Olson L, Ritzen M, Hokfelt T (1990) Expression of beta-nerve growth factor receptor mRNA in Sertoli cells downregulated by testosterone. Science 47:704-707.

Radeke MJ, Misko TP, Hsu C, Herzenberg LA, Shooter EM (1987) Gene transfer and molecular cloning of the rat nerve growth factor receptor. Nature 325:593-597.

Rodriguez-Tebar A, Dechant G, Barde Y-A (1990) Binding of brainderived neurotrophic factor to the nerve growth factor receptor. Neuron 4:487-492.

Rohrer H, Heumann R, Thoenen H (1988) The synthesis of nerve growth factor (NGF) in developing skin is independent of innervation. Dev Biol 128:240-244.

Rush RA (1984) Immunohistochemical localization of endogenous nerve growth factor. Nature 312:364-367.

Saunders JW, Gassling MT (1968) Ectodermal-mesenchymal inter- 
actions in the origin of limb symmetry. In: Epithelial-mesenchymal interactions (Fleischmejer R, Billingham RE, eds), pp 78-97. Baltimore: Williams and Wilkins.

Saxén L (1987) Organogenesis of the kidney. Cambridge UK: Cambridge University Press.

Seidl K, Holstein AF (1990) Organ culture of human seminiferous tubules: a useful tool to study the role of nerve growth factor in the testis. Cell Tissue Res 261:539-547.

Senut MC, Lamour Y, Lee J, Brachet P, Dicou E (1990) Neuronal localization of the nerve growth factor precursor-like immunoreactivity in the rat brain. Int J Dev Neurosci 8:65-80.

Shelton DL, Reichardt LF (1986) Studies on the regulation of betanerve growth factor gene expression in rat iris: the level of mRNA encoding nerve growth factor is increased in irises placed in explant culture in vitro, but not in irises deprived of sensory or sympathetic innervation in vivo. J Cell Biol 102:1940-1948.

Spooner BJ, Wessels NK (1970) Mammalian lung development: interactions in primordium formation and bronchial morphogenesis. $\mathrm{J}$ Exp Zool 175:445-454.

Sutter A, Tiopelle RJ, Harris-Warrick RM, Shooter EM (1979) Nerve growth factor receptors: characterization of two distinct classes of binding sites on chick embryo sensory ganglia cells. J Biol Chem 254: 5972-5982.

Thoenen H, Barde Y-A (1980) Physiology of nerve growth factor. Physiol Rev 60:1284-1335.

Thoenen H, Bandtlow C, Heumann R (1987) The physiological function of nerve growth factor in the central nervous system: comparison with the periphery. Rev Physiol Biochem Pharmacol 109:146-178.

Thompson S, Schatteman GC, Gown AM, Bothwell M (1989) A monoclonal antibody against nerve growth factor receptor: immunohistochemical analysis of normal and neoplastic human tissue. Am J Clin Pathol 92:415-423.
Thomson TM, Rettig WJ, Chesa PG, Green SH (1988) Expression of human nerve growth factor receptor on cells derived from all three germ layers. Exp Cell Res 174:533-539.

Thomson TM, Pellicer A, Greene LA (1989) Functional receptors for nerve growth factor on Ewing's sarcoma and Wilm's tumor cells. J Cell Physiol 141:60-64.

Tisher CG (1981) Anatomy of the kidney. In: The kidney, Vol 1 (Brenner B, Rector F, eds), pp 3-75. Philadelphia: Saunders.

von Bartheld CS, Patterson SL, Heuer JG, Wheeler EF, Bothwell M, Rubel EW (1991) Expression of nerve growth factor(NGF) receptors in the inner ear of chick and rat embryos. Development 113: 455470 .

Weintraub H, Tapcott S, Thayer M, Adam M, Lasser A, Miller AD (1989) Activation of muscle specific genes in pigment, nerve, fat, liver and fibroblast cell lines by forced expression of MyoD1. Proc Natl Acad Sci USA 86:5434-5438.

Wessels NK (1970) Mammalian lung development: interactions in formation and morphogenesis of tracheal buds. J Exp Zool 175:455466.

Wyatt S, Shooter EM, Davies AM (1990) Expression of the NGF receptor gene in sensory neurons and their cutaneous targets prior to and during innervation. Neuron 4:421-427.

Yan Q, Johnson EM (1988) An immunohistochemical study of the nerve growth factor receptor in developing rats. J Neurosci 8:34813498.

Yan Q, Snider WD, Pinzone JJ, Johnson EM Jr (1988) Retrograde transport of nerve growth factor (NGF) in motor ncurons of developing rats: assessment of potential neurotrophic effects. Neuron 1: 335-343. 